\title{
Structural Model of the Basement in the Central Savannah River Area, South Carolina and Georgia
}

by

D. Stephenson

Westinghouse Savannah River Company

Savannah River Site

Aiken, South Carolina 29808

A. Stieve

DOE Contract No. DE-AC09-89SR18035

This paper was prepared in connection with work done under the above contract number with the U.S. Department of Energy. By acceptance of this paper, the publisher and/or recipient acknowledges the U.S. Government's right to retain a nonexclusive, royalty-free license in and to any copyright covering this paper, along with the right to reproduce and to authorize others to reproduce all or part of the copyrighted paper.

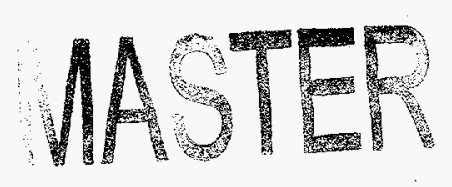

DISTRQUTOS OF THS DOCURENT IS UNLIMTED

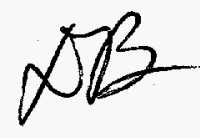




\section{DISCLAIMER}

This report was prepared as an account of work sponsored by an agency of the United States Government. Neither the United States Government nor any agency thereof, nor any of their employees, makes any warranty, express or implied, or assumes any legal liability or responsibility for the accuracy, completeness, or usefulness of any information, apparatus, product, or process disclosed, or represents that its use would not infringe privately owned rights. Reference herein to any specific commercial product, process, or service by trade name, trademark, manufacturer, or otherwise does not necessarily constitute or imply its endorsement, recommendation, or favoring by the United States Government or any agency thereof. The views and opinions of authors expressed herein do not necessarily state or reflect those of the United States Government or any agency thereof.

This report has been reproduced directly from the best available copy.

Available to DOE and DOE contractors from the Office of Scientific and Technical Information, P. O. Box 62, Oak Ridge, TN 37831; prices available from (423) 576-8401.

Available to the public from the National Technical Information Service, U. S. Department of Commerce, 5285 Port Royal Road, Springfield, VA 22161. 


\section{DISCLAIMER}

Portions of this document may be illegible electronic image products. Images are produced from the best available original document. 
WSRC-TR-92-120

\section{STRUCTURAL MODEL OF THE BASEMENT IN THE CSRA, SOUTH CAROLINA, AND GEORGIA (U)}

by

Dale Stephenson and Alice Stieve

Environmental Sciences Section

Westinghouse Savannah River Company

Savannah River Technology Center

This is a Technical Report

This report was prepared in connection with work done under Contract No. DE-AC09-89SR18035 with the U.S. Department of Energy. By acceptance of this report, the publisher and/or recipient acknowledges the U.S. Government's right to retain a nonexclusive, royalty-free license in and to any copyright covering this report, along with the right to reproduce and to authorize others to reproduce all or part of the copyrighted report. 
Derivative Classifiex Dorome - Lherw

WSRC-TR-92-120

D. B. Moore-Shedrow, Section Manager

Structural model of the basement in the Central Savannah River Area, South Carolina and Georgia (U)

Dale Stephenson and Alice Stieve

Environmental Sciences Section

Westinghouse Savannah River Company

Savannah River Technology Center

March 31, 1992

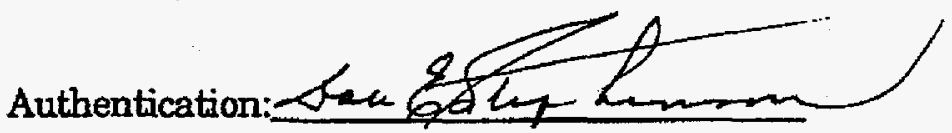

Approved by:DRmane- Akehn-

D. B. Moore-Shedrow, Manager

Environmental Sciences Section

Savannah River Technology Center

WESTINGHOUSE SAVANNAH RIVER COMPANY

SAVANNAH RIVER SITE

Aiken, South Carolina 29808

Prepared for the U. S. Department of Energy under

Contract No. DE-AC09-89SR18035

$$
4 .
$$




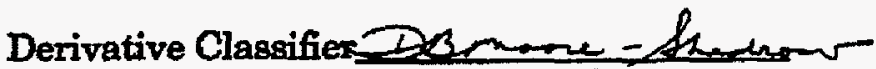

WSRC-TR-92-120

D. B. Moore-Shedrow, Section Manager

Structural model of the basement in the Central Savannah River Area, South Carolina and Georgia (U)

Dale Stephenson and Alice Stieve

Environmental Sciences Section

Westinghouse Savannah River Company

Savannah River Technology Center

March 31, 1992

Authentication: $\operatorname{sen} 6 \theta$

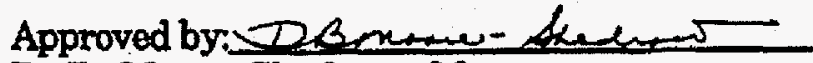

D. B. Moore-Shedrow, Manager

Environmental Sciences Section

Savannah River Technology Center

WESTINGHOUSE SAVANNAH RIVER COMPANY

SAVANNAH RTVER SITE

Aiken, South Carolina 29808

Prepared for the U. S. Department of Energy under

Contract No. DE-AC09-89SR18035 


\begin{abstract}
Interpretation of several generations of seismic reflection data and potential field data suggests the presence of several crustal blocks within the basement beneath the Coastal Plain in the Central Savannah River Area (CSRA). The seismic reflection and refraction data include a grid of profiles that capture shallow and deep reflection events and traverse the Savannah River Site and vicinity. Potential field data includes aeromagnetic, ground magnetic surveys, reconnaissance and detailed gravity surveys. Subsurface data from recovered core are used to constrain the model.

Interpretation of these data characteristically indicate a southeast dipping basement surface with some minor highs and lows suggesting an erosional pre-Cretaceous unconformity. This surface is interrupted by several basement faults, most of which offset only early Cretaceous sedimentary horizons overlying the erosional surface. The oldest fault is perhaps late Paleozoic because it is truncated at the basement/ Coastal Plain interface. This fault is related in timing and mechanism to the underlying Augusta fault. The youngest faults deform Coastal Plain sediments of at least Priabonian age (40-36.6 Ma). One of these young faults is the Pen Branch fault, identified as the southeast dipping master fault for the Triassic Dunbarton basin. All the Cenozoic faults are probably related in time and mechanism to the nearby, well studied Belair fault.

The study area thus contains a set of structures evolved from the Alleghanian orogeny through Mesozoic extension to Cenozoic readjustment of the crust. There is a metamorphosed crystalline terrane with several reflector/fault packages, a reactivated Triassic basin, a mafic terrane separating the Dunbarton basin from the large South Georgia basin to the southeast, and an overprint of reverse faults, some reactivated, and some newly formed.
\end{abstract}




\section{Table of Contents}

INTRODUCTION

Geologic Background

Coastal Plain Section

Metamorphic Basement

Dunbarton Triassic Rift Basin

p 1

p 1

p 1

p 2

DATA

p 2

Seismic Reflection Programs

Gravity Surveys

Magnetic Surveys

p 2

p 4

$\mathrm{p} 4$

Time Domain Electromagnetic Survey

p 5

INTERPRETATION OF FAULTS

p 5

REGIONAL CONTEXT

p 9

CONCLUSIONS

$\mathrm{p} 12$

REFERENCES

p 13

4. 


\section{List of Figures and Tables}

Figure 1. Location of Study area

Figure 2. Location of faults in the subsurface at Savannah River Site.

Figure 3. Digital single fold seismic reflection survey obtained by Seismograph Services Corporation in 1969 and 1979.

Figure 4. Seismic reflection structure contour map of Savannah River Site with interpreted faults and discontinuities (Seismograph Services Corporation).

Figure 5. Conoco Inc. Seismic Reflection Survey index map

Figure 6. Emerald Exploration Consultants, Inc., 1990-1991 seismic reflection survey index map.

Figure 7. Gravity map of Central Savannah River Area (Anderson, 1990).

Figure 8. USGS aeromagnetic map

Figure 9. Seismograph Services Corporation vertical magnetic map

Figure 10 TDEM structure contour of the crystalline basement

Figure 11. Conoco Seismic Reflection Profile Line 2exp, detailed view of Pen Branch fault.

Figure 12. Conoco line 4 showing Pen Branch fault and inclined strata of the Dunbarton basin.

Figure 13. Conoco line 1 showing Pen Branch and Steele Creek fault.

Figure 14. Conoco line 27 Atta fault, northern line.

Figure 15. Conoco line 9 Atta fault, southern line.

Figure 16. Conoco line 1; Crackerneck fault.

Figure 17. Conoco line 4; 6 second record showing Pen Branch fault, Dunbarton basin, Upper Three Runs and Augusta faults.

Figure 18. Conoco line 13, Southern boundary of the Triassic basin showing mafic sills.

Figure 19. Cross-section of Triassic başin

Figure 20. Geologic map showing the Augusta and Belair faults in Georgia and South Carolina (from figure 1 Bramlett and others, 1982). Savannah River Site is located just off the lower right hand corner of illustration. 4 . 
Figure 21. Cross-section of transect from just north of plant boundary to the southeast to include the South Georgia Rift complex.

Figure 22. Southeastern regional map of subsurface Triassic basins (from Figure 1 of McBride and others, 1989). Heavy lines outline the Triassic-Jurasic subcrop, intermediate lines indicate seismic reflection data, and thin lines represent exposed diabase dike outcrops in the Piedmont. Dots indicate drill hole data.

Table 1. Seismograph Services Corporation Acquisition Parameters

Table 2. Conoco Inc. Acquisition Parameters

Table 3. EMEX Acquisition Parameters 


\section{INTRODUCTION}

During forty plus years of work at the Savannah River Site almost continuous geological and geophysical investigations have been performed at the site and in the general Central Savannah River Area (CSRA)(Figure 1). The majority of the studies have been concentrated on the sediments of the Coastal Plain. The data on the underlying basement are much more limited and depend upon the interpretation of a few deep borings and geophysical surveys. Standard seismic and high-resolution, shallow seismic reflection and refraction data in conjunction with potential field data and constrained by the available geologic data from deep cores have been used to develop a model of structure within the basement complex.

Interpretation of these data characteristically indicate a southeast dipping basement surface with some minor highs and lows suggesting an erosional surface (pre-Cretaceous unconformity). This surface is interrupted by several basement faults, most of which offset only early Cretaceous sedimentary horizons overlying the erosional surface (Figure 2). The oldest fault is perhaps late Paleozoic because it is truncated at the basement/Coastal Plain interface. The youngest fault may be Tertiary-age because deformed sediments of that age in the Coastal Plain are observed directly overlying this fault. These faults form groups or sets of faults based on age and regional correlation to other known faults.

\section{GEOLOGIC BACKGROUND}

Coastal Plain Section. The Central Savannah River Area is located on the Atlantic Coastal Plain, which is an essentially flat-lying, undeformed wedge of unconsolidated marine and fluvial sediments. The sediments are stratified sand, clay, limestone, and gravel that dip gently seaward and range in age from Late Cretaceous to Recent. The sedimentary sequence thickens from zero at the Fall Line to more than $1.2 \mathrm{~km}$ at the coast. There are about 185 to $370 \mathrm{~m}$ of section at Savannah River Site. The Coastal Plain section is divided into several groups based principally on age and lithology (Aadland, and Bledsoe, 1990).

Beneath the Coastal Plain sedimentary sequence at the Savannah River Site, below a pre-Cretaceous unconformity, are two geologic terranes; 1) a TriassicJurassic rift basin, the Dunbarton basin, filled with lithified terrigenous and lacustrine sediments with minor amounts of mafic volcanic and intrusive rock (Marine, 1974 a and b; Marine and Siple, 1974) and 2) a crystalline terrane of metamorphosed sedimentary and igneous rock that may range in age from Precambrian to late Paleozoic. The Paleozoic rocks and the Triassic sediments were leveled by erosion, forming the base for Coastal Plain sediment deposition. The erosional surface dips approximately $8 \mathrm{~m} / \mathrm{km}$ toward the southeast.

Metamorphic Basement. The metamorphosed crystalline rock is similar to that found in the Piedmont Province immediately northwest of the fall line, 20-25 km northwest of the Savannah River Site. Preliminary work on drill core lithology suggests that Kiokee Belt and Belair Belt rock may be found in core taken at the Savannah River Site. There are probable greenschist facies volcanic rock in the 


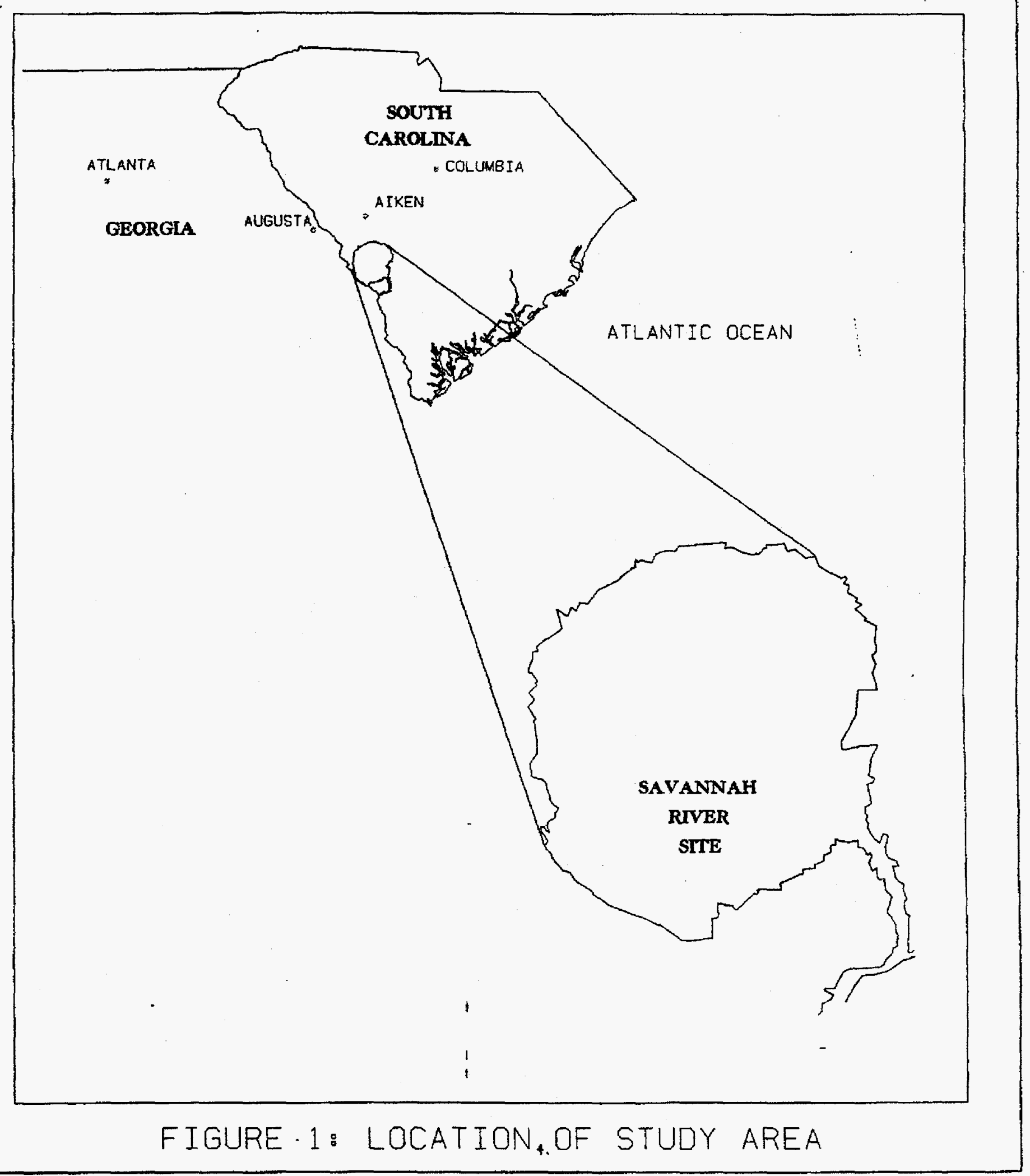







Deep Rock Boring well series (Marine, 1974 a \& b) and the Pen Branch Fault wells contained biotite gneiss and amphibolite. Between New Ellenton and Aiken granite and granitic gneiss have been identified in core.

Dunbarton Triassic Rift Basin. The Dunbarton basin has been the subject of investigation since Siple (1967) identified the basin from aeromagnetic and well data. Subsequent seismic reflection surveys and additional well data were described by Marine (1974a and b), and Marine and Siple (1974). The structure was interpreted as an asymmetric graben approximately 50 kilometers long and $\mathbf{1 0}$ to $\mathbf{1 5}$ kilometers wide with normal faults to the northwest and southeast.

Additional investigations were conducted at the Savannah River Site from 1985 to 1991 such as standard seismic reflection, potential field surveys, in situ stress measurements, and high-resolution shallow seismic reflection surveys. These studies were initiated to determine the cause of two micro-earthquakes that occurred at the site in 1985 (Local magnitude: 2.6, Talwani and others, 1985) and in 1988 (Local Magnitude: 2.0, Stephenson, 1988) and to better understand the deformational history of Coastal Plain material.

\section{DATA}

\section{SEISMIC REFLECTION PROGRAMS}

Since 1969, four seismic reflection surveys were conducted at the Savannah River Site. The oldest survey on site was digital single fold data obtained by Seismograph Service Corporation in 1969 and 1970 (Figure 3). These surveys gave the first indication of the basement faults buried underneath the Coastal Plain section in this region (Figure 4). This work was performed as part of the Bedrock Waste Storage Program for the purpose of obtaining information on the attitude of the bedrock surface and to determine the strike of faults and the position of the Triassic basin. A total of about 139 line $\mathbf{~ k m}$ of surface coverage were obtained in three field programs. The principle area investigated by these surveys was to the southeast of the Aiken-Barnwell county line. Seismograph Service Corporation utilized a 24-channel digital recording system, $278 \mathrm{~m}$ between shot points, and about $0.45 \mathrm{~kg}$ of high explosive per shot. Field acquisition parameters are indicated in Table 1.

In 1978 D'Appolonia, Inc. conducted a high resolution minisosie reflection survey (Murdock, 1982) in the proposed Away From Reactor Spent Fuel Storage Facility (AFR) area. This detailed survey (15 line $\mathrm{km}$ ) utilized a 24 -trace recording system with a $1-\mathrm{ms}$ sample rate. The shot to first trace offset was $148 \mathrm{~m}$, trace spacing was $12.3 \mathrm{~m}$, and shot to far trace offset was $432 \mathrm{~m}$. The large offset between the seismic source and the first trace precluded the recording of data between the surface and $250 \mathrm{ft}$. The data were obtained as 6 fold.

A vibroseis seismic reflection survey was conducted at the Savannah River Site in 1987-88 by Conoco Inc. (Chapman and DiStefano, 1989) (Figure 5). The primary objective at the onset of the program was to better define basement structure and previously identified faults and to identify any other faults that might exist. A 


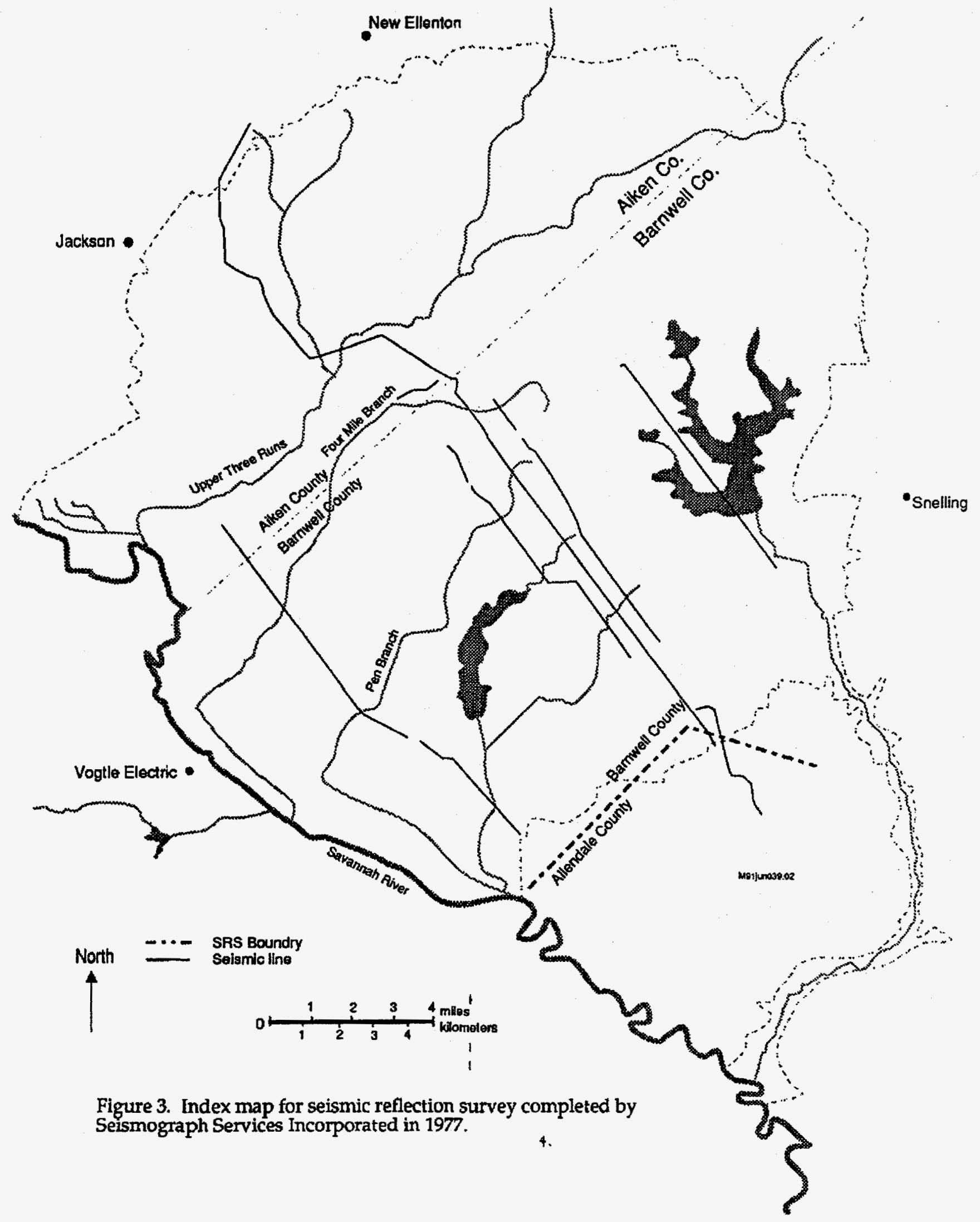




\section{NEAR TOP OF TRIASSIC \& CRYSTALLINE ROCK}

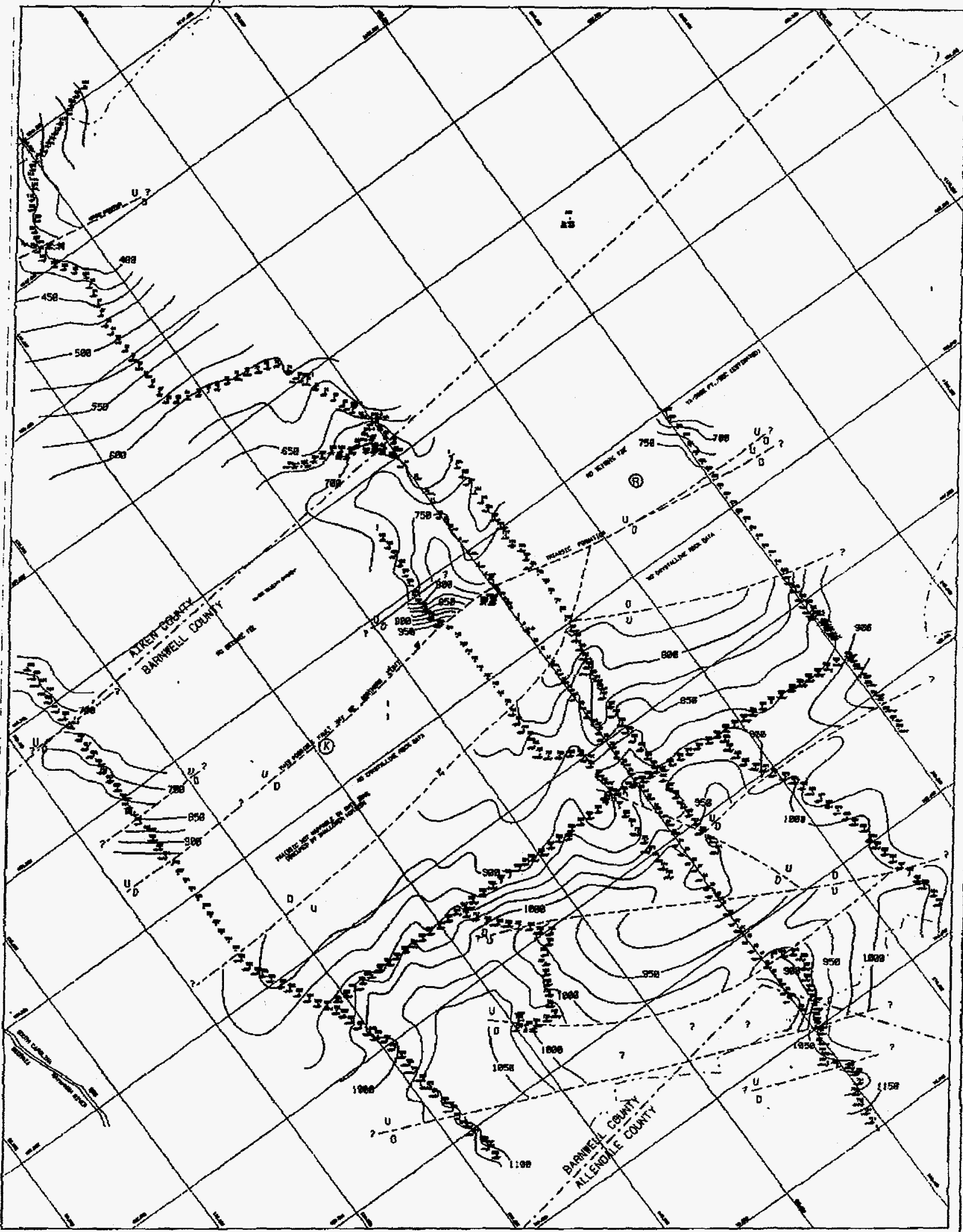

Lecan

ion

rand

totime

-

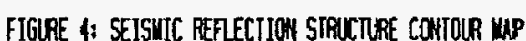

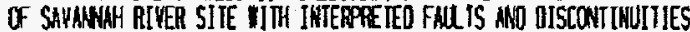
ISEISMGRPAH SERYICES CORPORKTION\}.

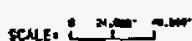

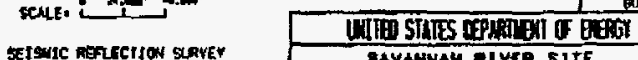

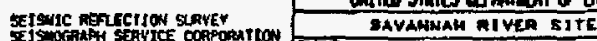

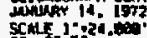
Cli

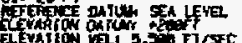

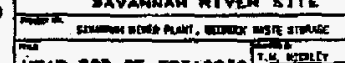

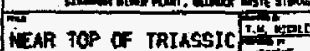

VEAR TOP OF TRIASSIC Vut Th

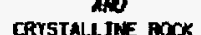


Table 1 Acquisition Parameters for Seismograph Services Inc. seismic reflection survey.

\begin{tabular}{l|l}
\hline Recording System & TI DFS-III digital, 24 channel \\
\hline Fold & 1 \\
\hline Shot Interval & $900 \mathrm{ft}$ \\
\hline Near offset & $75 \mathrm{ft}$ \\
\hline Geophone spacing & $75 \mathrm{ft}$ \\
\hline Geophone Array & 10 spaced parallel to the line \\
\hline Geophone Frequency & HSJ-14 Hz \\
\hline Spread geometry & symmetric, split spread \\
\hline Energy Source & 1 lb. charge, Nitramon or \\
\hline Shot holes & Primacord \\
\hline Well control & 40 to I30 ft depth \\
\hline
\end{tabular}

4. 


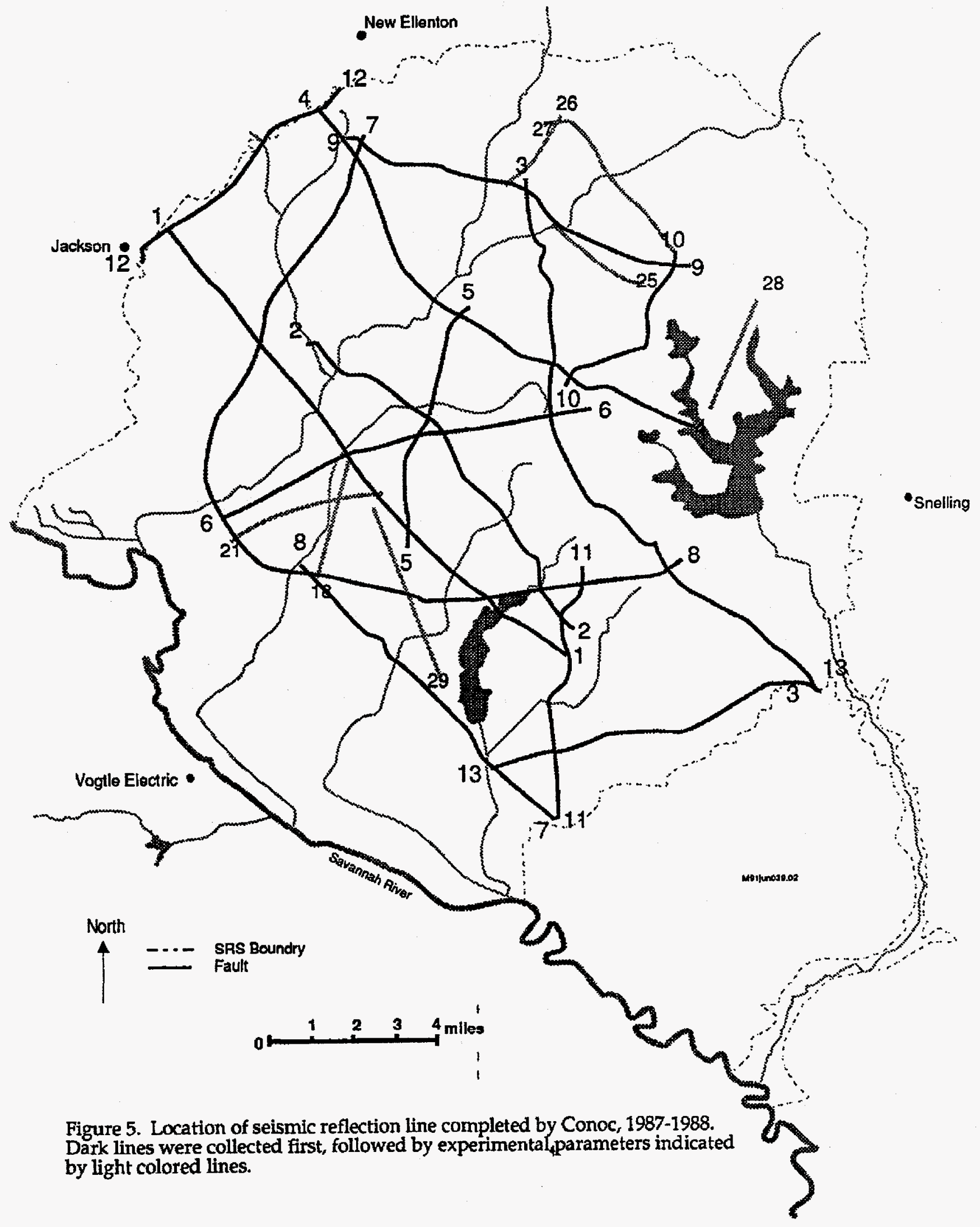


secondary objective was to image any shallower or deeper structure that appeared on the seismic records. These data capture energy from 0.1 to about 13 seconds.

An initial 216 line $\mathrm{km}$ of seismic reflection data were acquired over the central part of the Savannah River Site. Initial parameters were selected to provide data for both reflection and refraction analysis. The refraction data provided a backup data set for basement mapping. The initial seismic acquisition parameters listed in Table 2 column A were used on the first 5 lines recorded (lines 1, 4, 6, 7, and 8). Initial processing indicated that the reflection data quality was sufficient to satisfy the objectives and that the longer refraction geometries were not necessary. For this reason, the parameters listed in column B on Table 2 were used on the remainder of the lines recorded. The column B parameters were more singly focused for mapping the shallow basement reflector with the maximum offset at $617 \mathrm{~m}$ and sourcing of $25 \mathrm{~m}$ spacing providing data for 24 fold CDP stack. The results of the preliminary interpretation highlighted areas that required additional definition. An additional 45 line $\mathrm{km}$ (8 lines) were then acquired to fill in these specific areas with greater detail. Three shallow vertical velocity surveys were also conducted to provide time-depth calibration for the seismic reflection data.

Emerald Exploration Consultants, Inc. (EMEX) conducted a high-resolution, shallow seismic reflection survey at the Savannah River Site (Stieve, 1991, Berkman, 1991). The purpose of this survey was to determine the shallowest extent of the Pen Branch fault and to determine the presence of any flat-lying, undeformed layers over the fault. The survey was to acquire, process, and interpret $28 \mathrm{~km}$ of high resolution seismic reflection data taken across the trace of the Pen Branch fault and other suspected, intersecting north-south trending faults (Figure 6). Field acquisition and processing parameters were selected to optimize for the upper $92 \mathrm{~m}$ of geologic strata where previous data suggested the fault terminated. Other geophysical, borehole, and geologic data were incorporated into the investigation to assist in the determination of optimal parameters and aid in the interpretation. The standard seismic reflection data (Conoco, 1987-1988) overlap or intersect some of the high-resolution, shallow seismic reflection lines (EMEX, 1990-1991).

The acquisition program for the shallow seismic survey consisted of an asymmetric split-spread layout with parameters listed in Table 3 . The last two lines run in this survey used a greater near offset than the other lines. These parameters are also listed in Table 3. These parameters were intended to focus on a deeper zone immediately above basement and outside the noise cone. Reversed refraction shots were taken at both ends of each line. Filter and charge size tests were repeated periodically.

In general, all the seismic reflection data show features that reflect current understanding of the regional geology of the Coastal Plain. Survey profiles demonstrate a seaward thickening section with regional dip to the southeast. The reflectors in the upper $305 \mathrm{~m}$ of the seismic data are interpreted to be predominantly sand/clay interfaces and clastic/carbonate interfaces. Some are believed to be caused by impedance contrasts across regional unconformities. Seismic structures observed, such as low and high frequency undulations, 
Table 2 Acquisition Parameters for the Conoco seismic reflection

\begin{tabular}{l|l|l|l}
\hline & A & B & C \\
\hline Flag spacing & 55 & 40 & 20 \\
\hline CDP Stack (fold) & 48 & 24 & 20 \\
\hline Near offset (ft) & 137 & 140 & 50 \\
\hline Far offset (ft) & 2722 & 2020 & 990 \\
\hline Sweep frequencies (Hz) & $20-120$ & $20-$ & $30-$ \\
& & 120 & 150 \\
\hline Length (sec) & 10 & 10 & 8 \\
\hline Source & $3 \times 6$ & $3 \times 6$ & $1 \times 4$ \\
\hline Array length (ft) & 90 & 90 & 0 \\
\hline Geophones & $1 \times 14$ & $1 \times 14$ & $1 \times 14$ \\
\hline Array length (ft) & 55 & 55 & 0 \\
\hline Record time (ses) & 14 & 14 & 10 \\
\hline $\begin{array}{l}\text { Sample rate } \\
\text { (milliseconds) }\end{array}$ & 2 & 2 & 2 \\
\hline Alias filter & & & \\
\hline Low cut filter & 2 & 2 & 2 \\
\hline Slope & 18 & 18 & 30 \\
\hline 60 Hz notch & 18 & 18 & 18 \\
\hline COS box & out & out & out \\
\hline & in & in & in \\
\hline
\end{tabular}

Table 3 Acquisition Parameters for Highresolution, shallow seismic reflection (EMEX).

\begin{tabular}{|c|c|}
\hline Recording System & 24 channel EGG 2401 \\
\hline Sample Rate & $0.2 \mathrm{~ms}$ \\
\hline Record Length & 0.400 second \\
\hline Shot Location & \begin{tabular}{|l|} 
Trace 4 or 4.5 \\
\end{tabular} \\
\hline Shot Interval & $10 \mathrm{ft}$ \\
\hline Trace Interval & $20 \mathrm{ft}$ \\
\hline $\begin{array}{l}\text { Subsurface Trace } \\
\text { Spacing }\end{array}$ & $5 \mathrm{ft}$ \\
\hline Fold & 12 \\
\hline Geophone Array & $\begin{array}{l}6 \text { - spaced over } 1.5 \mathrm{ft} \\
\text { parallel to the line }\end{array}$ \\
\hline Geophone Frequ & $40 \mathrm{~Hz}, 3$ inch spike \\
\hline Energy Source & $\begin{array}{l}\text { Buffalo Gun - 12-Gauge } \\
\text { light load }\end{array}$ \\
\hline Filter & $\begin{array}{l}50-1000 \mathrm{~Hz} \text {, with } 60 \mathrm{~Hz} \\
\text { notch }\end{array}$ \\
\hline
\end{tabular}

4. 


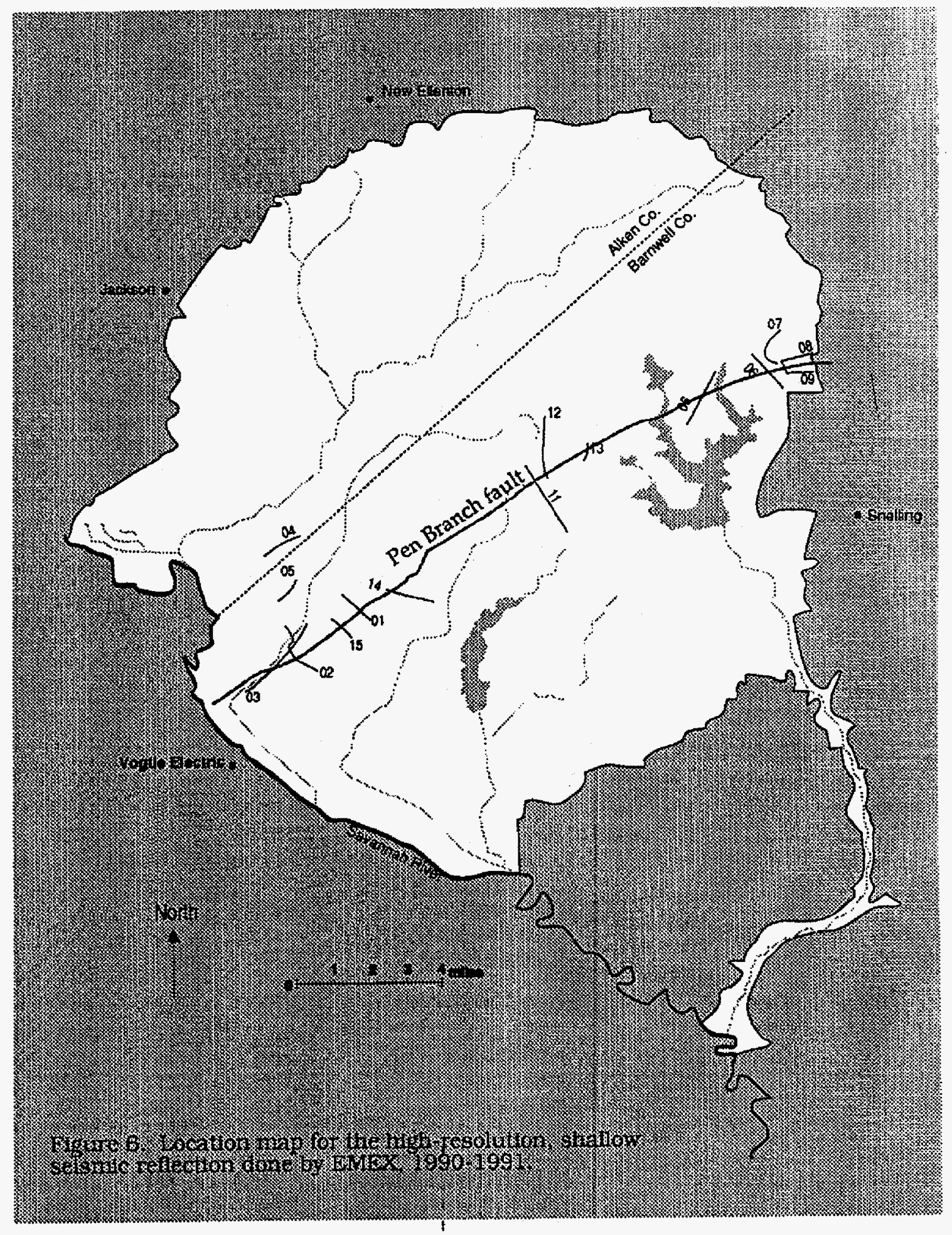

4. 
truncated and offset reflectors, intermittent reflectors, are interpreted to be faults, possible folding or deformation, sedimentary facies changes, and narrow to wide stream channels, point bars or overbank deposits. Below the Coastal Plain crystalline metamorphic and Triassic/Jurasic age rock, the basement complex contains structures and characteristics that provide additional insight into the geologic framework of the area.

\section{GRAVITY SURVEYS}

Gravity data for the Savannah River Site are available from three sources; 1) general regional gravity from the state maps of Georgia and South Carolina (Long and Talwani, 19), 2) the 1971 Birdwell survey, and 3) two studies by the University of South Carolina (Anderson, 1989 and Madubhushi and Talwani, 1991). These studies, especially the later two, were performed for the purpose of identifying and mapping basement and deep seated structures.

In 1971, Birdwell Division of Seismograph Services Corporation performed a gravity survey in conjunction with a ground magnetic survey of the southern portion of the site as a part of the Bedrock Waste Storage Program. The purpose of this survey was to determine the depth and lateral extent of the Triassic Dumbarton basin and the apparent dip of basement faults recognized on the seismic reflection survey. The data obtained in this survey are only relative values because the lines were not tied to any base stations of the existing gravity networks. Modeling of these data by Birdwell indicated the Dunbarton basin to be about $2 \mathrm{~km}$ deep and contain a number of fault blocks with about $0.6 \mathrm{~km}$ of displacement on the northwest border fault. The Triassic sediments are underlain by dense crystalline rock.

A second detailed gravity survey was performed by Anderson (1990) during the period of 1986-1988 (Figure 7). During this investigation gravity data were obtained with a Worden gravimeter, model 112 occupying 1134 stations at about $0.46 \mathrm{~km}$ spacing mostly on the Savannah River Site but also in the surrounding area. The survey established 79 overlapping loops and base stations were reoccupied at less than 2.5 hour intervals. The maximum local relief was 50 to $250 \mathrm{~m}$. Within the Savannah River Site, repeatability of data at stations was less than $0.2 \mathrm{mgals}$ and in the region surrounding it was less that $0.5 \mathrm{mgals}$. Bouguer gravity maps were constructed to detail the deeper seated features in the bedrock (1mgal and $0.5 \mathrm{mgal}$ maps). A regional gravity survey (Madubhushi and Talwani, 1991) incorporated a larger portion of the middle state region, but was taken at a lower station density.

\section{MAGNETIC SURVEYS}

The United States Geological Survey conducted an aeromagnetic survey of the Savannah River Site region (1958) at the request of Atomic Energy Commission (Figure 8). The survey covered a $160 \mathrm{~km}^{2}$ area, centered on the site. Northwestsoutheast flight lines were spaced at $1.6 \mathrm{rm}$ intervals and flown at $152 \mathrm{~m}$ above ground surface (Petty, and others, 1965). Daniels (1974) reanalyzed these data and modified the map of Petty and others (1965) by combining geologic data from core. 


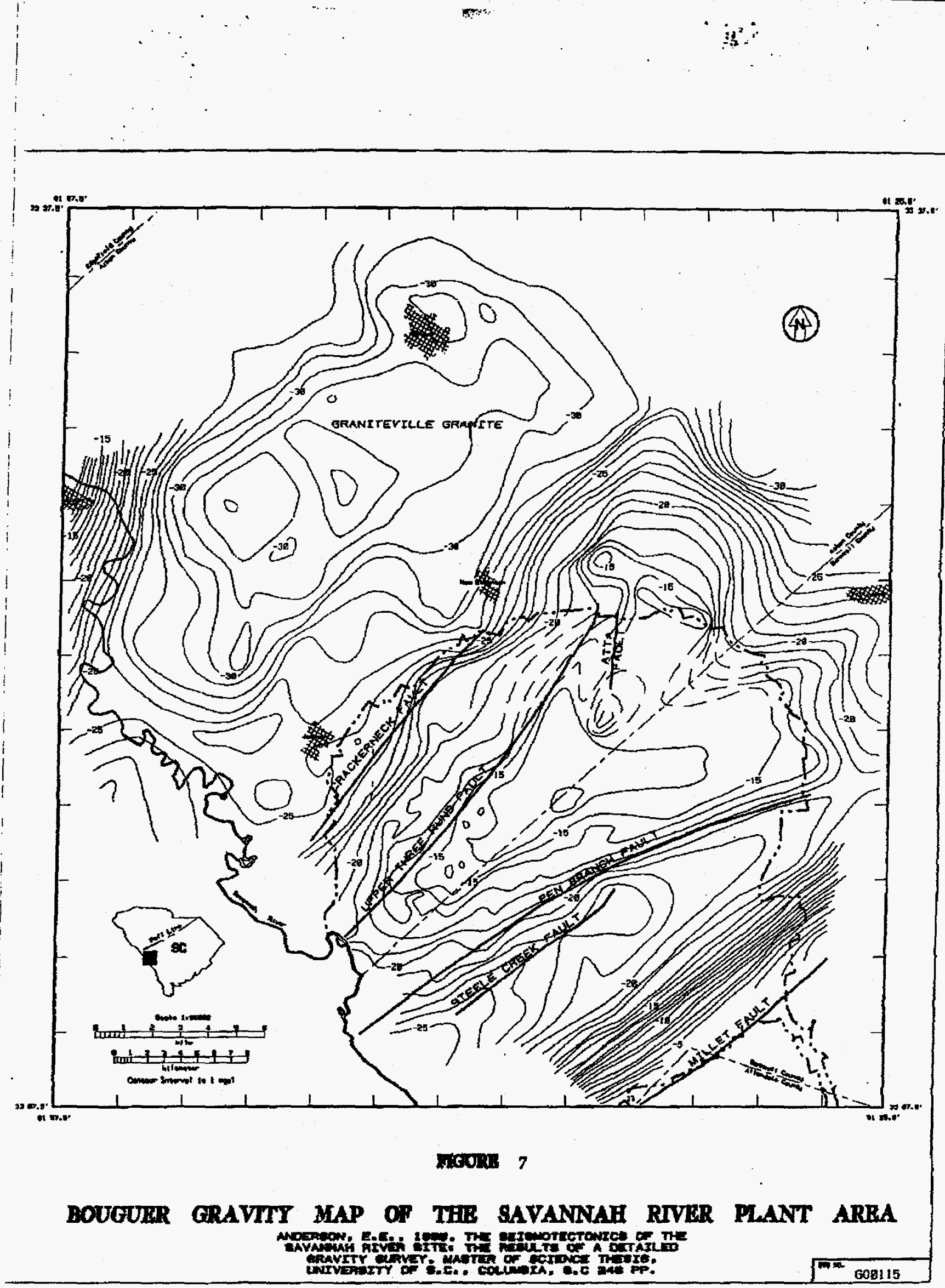




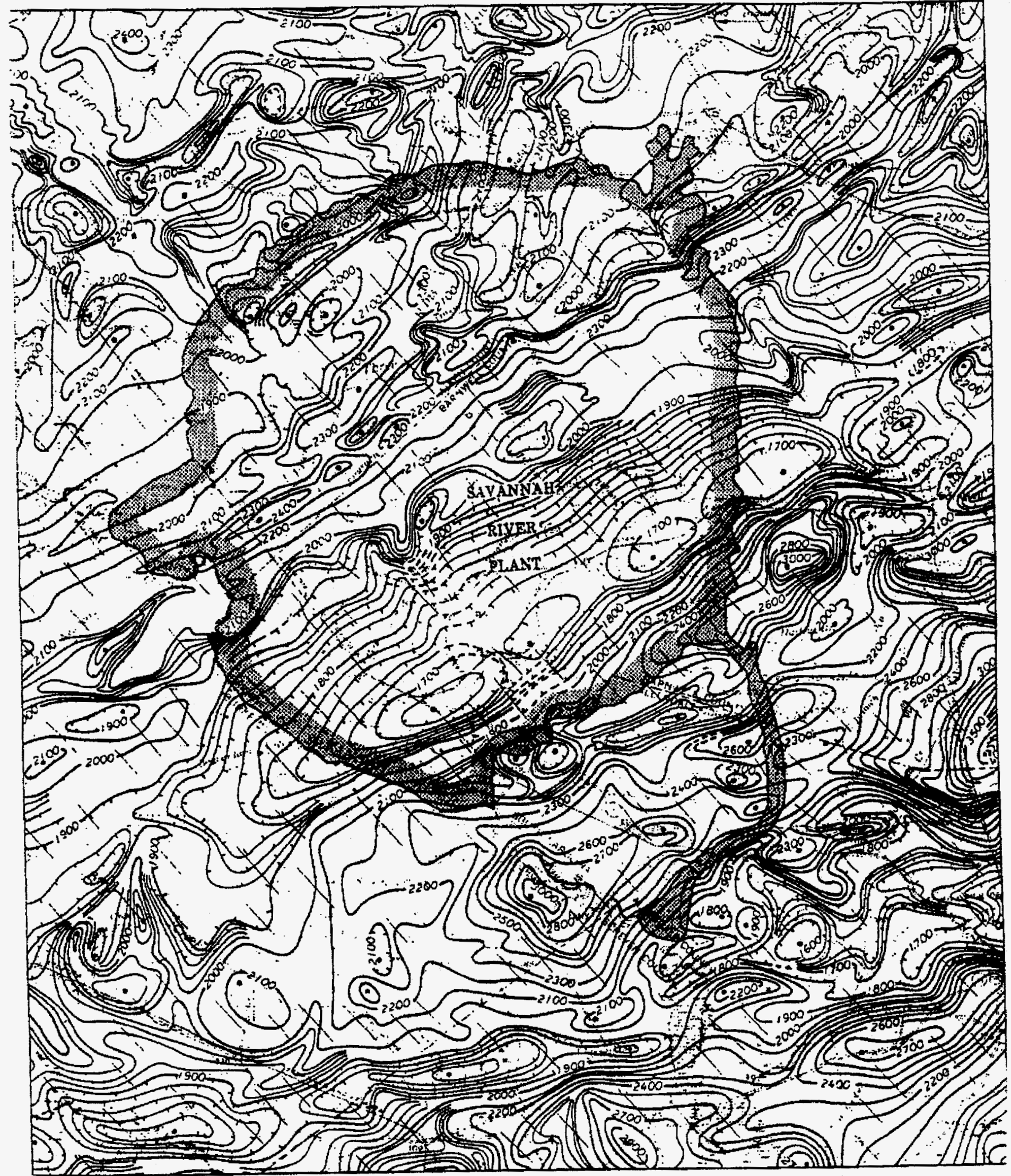

Figure 8. USGS aeromagnetic map 
In 1972 the Birdwell Division of Seismograph Services performed a surface magnetic survey of the southern portion of the site following seismic lines and extending to the southeast off site as far as the community of Fairfax SC (Figure 9). No data were obtained in the northwestern portion of the site during this survey.

\section{TIME DOMAIN ELECTROMAGNETIC (TDEM) SURVEY}

Blackhawk Geosciences Inc. conducted a survey at the Savannah River Site in 1989 with the objective to determine the depth and geometry of the Dunbarton basin (Figure 10). Out of 124 total stations, 80 TDEM stations detected basement with an areal distribution of $1 / 4 \mathrm{mi}^{2}$. Three different system were used to maximize different depth determinations; Geonics EM-42, EM-37, EM-47. A nongrounded loop transmitter was used with a center loop array. Blackhawk Geosciences Inc. concluded, based on the TDEM survey, that the bottom of the Triassic basin was approximately $1.8 \mathrm{~km}$ deep.

\section{NTERPRETATION OF FAULTS}

Several faults have been interpreted in the subsurface at the Savannah River Site based upon these geophysical data (Figure 2). With the integration and interpretation of all the geophysical data, a model of the subsurface geology including the deeper basement structure has been made possible. Several faults have been corroborated or newly identified:

1. Pen Branch fault (PBF); initially identified as the northern boundary fault of the Triassic basin.

2. Steel Creek fault (SCF); a fault southeast of PBF within the Triassic basin and forming a horst with PBF.

3. Atta fault(AF); the north, northeast trending fault in the north-central portion of the Savannah River Site.

4. Ellenton fault (EF); a north-south trending fault, east of D Area that may intersect the PBF.

5. Crackerneck fault (CF); a northeast trending fault located in the northwest portion of the Savannah River Site.

6. Upper Three Runs fault(UTRF); a northeast trending fault that underlies the current Upper Three Runs drainage.

All of these faults are initially described for the purposes of this report from seismic reflection data. Gravity, magnetic, and TDEM surveys, drill core data corroborate specified individual faults at various levels of confidence.

The Pen Branch fault (PBF) (Figure 1) was first identified in the subsurface at the Savannah River Site in 1989 based upon interpretation of earlier seismic reflection surveys and other geologic innestigations (Marine and Siple, 1974; Seismograph Services Incorp., 1973; Chapman and DiStefano, 1989; Snipes, Fallaw and Price, 1989; Stieve and others,1991). The fault constitutes a possible continuation of the northern boundary fault of the Triassic Dunbarton basin and strikes northeast across the middle of Savannah River Site, parallel to the boundary of the Triassic Dunbarton rift basin. It is the longest and one of the shallowest of the faults in the study area and dips to the southeast. In the 


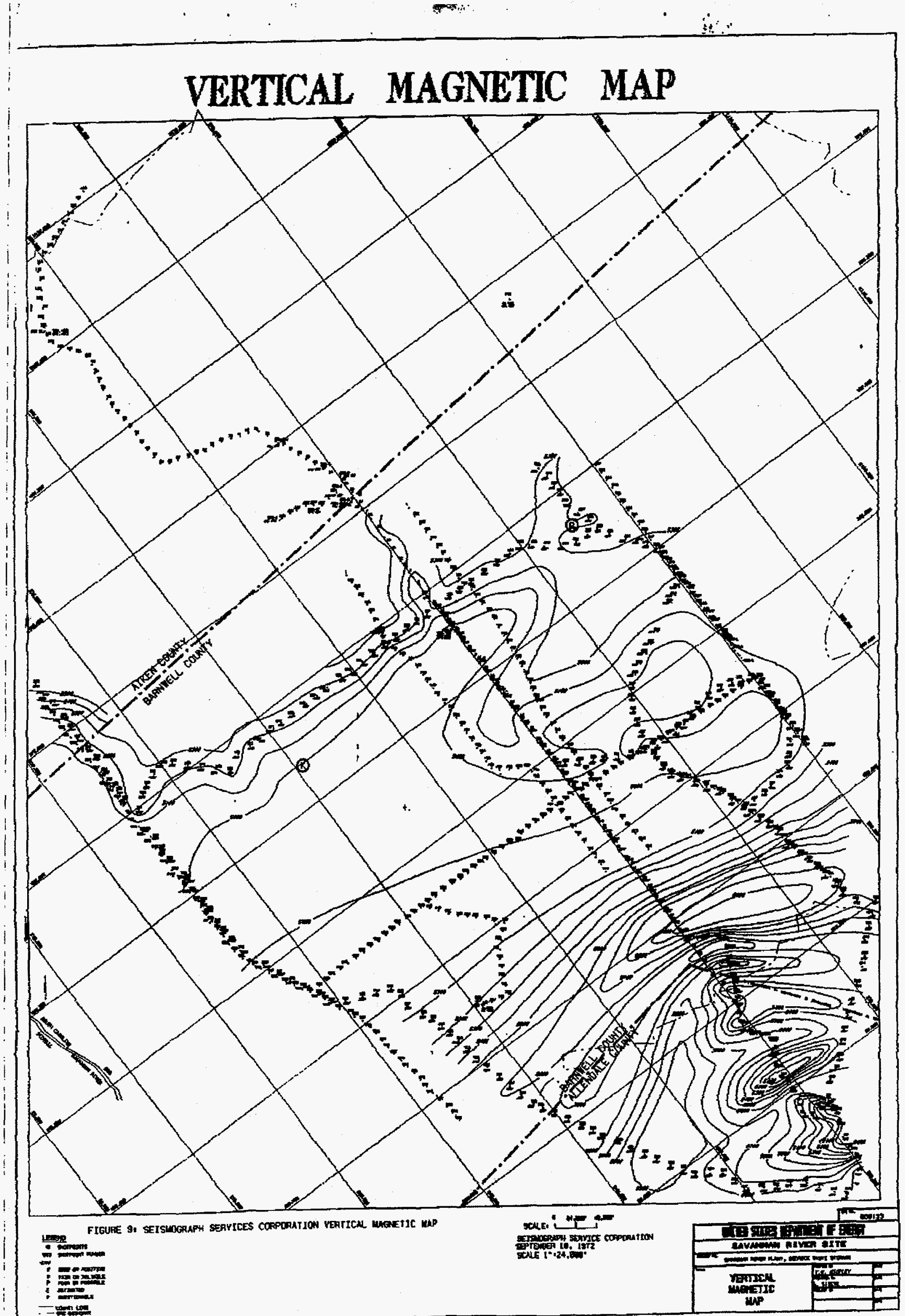




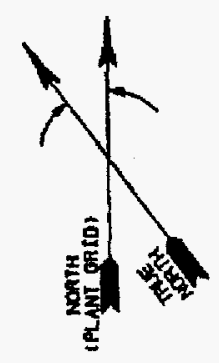


crystalline basement, normal slip direction was originally down to the southeast resulting in the formation of the rift basin. However, reverse movement during Cretaceous into Tertiary time is up to the southeast (Stephenson and Chapman, 1988; Snipes and others, 1989). Based on drill core data, Triassic rock is known to be structurally higher than crystalline basement (Snipes and others, 1989; Stieve and others, 1991). Based on focal plane solutions, there could also be a component of strike-slip movement on the fault (Stephenson and others, 1985).

The 1974 seismic survey (Seismograph Services Corp.) crossed the fault with 5 lines. The data suggested a zone of disturbed layers in the vicinity of the currently mapped trace of the Pen Branch fault (Figure 4). In the Conoco (1987-88) survey, a total of 9 lines cross the border fault, clearly showing the fault and providing good control for mapping its location.

Three lines from the Conoco survey, reprocessed by VPI (ongoing work), serve to illustrate current understanding of the seismic expression of the Pen Branch fault. Conoco line 2 exp displays typical PBF geometry plus the shallowest data collected during this survey (Figure 11, shot point 715). The fault dips southeast at $\sim 50^{\circ}$ in Coastal Plain section and shallows to $\sim 40^{\circ}$ in basement. The basement reflector is offset at $400 \mathrm{msec}$ and reflectors up to $250 \mathrm{msec}$ show deformation over the fault. At $200 \mathrm{msec}$ is the interpreted green clay interval, expressed as a continuous recognizable reflector. It is not certain that the slight undulation observed in this layer is due to erosion or tectonic deformation (shot points 700 715). There are continuous reflectors up to $40 \mathrm{msec}$ of the datum and one of these reflectors is perhaps the 'Upland' unconformity. Conoco line 4 shows PBF in Coastal Plain sediments up to $250 \mathrm{msec}$ (Figure 12). The $200 \mathrm{msec}$ reflector is not well expressed over the fault in this line. The character of the fault in the crystalline rock is remarkable. The dip on the fault becomes shallower as it wraps around the base of the basin. This aspect of the structure is further exemplified in figure 17. The southeast dipping reflectors in figure 12 are Triassic red bed layers dipping away from the fault. Conoco line 1 shows an atypical, complicated geometry for the fault (Figure 13). There is a small splay just to the northeast of the main fault.

The evidence for the Pen Branch fault in the gravity, aeromagnetic, and time domain electo-magnetic data are secondary inferences based on a well-defined northwest boundary to the Dunbarton basin seen in those data (Figure 7, 8, 9,10).

Steele Creek fault is located southwest of the PBF, within the Dunbarton basin. The fault trends generally northeast. The offset of the fault is down to the southeast and thus forms a horst with the Pen Branch fault (Figure 2). Above the Triassic rock, the fault offsets some Cretaceous horizons but the shallowest extent of the fault is not well constrained. It is located on fewer seismic reflection lines than the PBF. Conoco line 1 demonstrates the Steele Creek fault in relation to the Pen Branch fault (shot point 1025). In this profile, the horst is easily observed and the Steele Creek fault can be traced up to -250 msec two way travel time. The Seismograph Services Corporation seismic reflection data located the Steele Creek fault on 4 survey lines. 


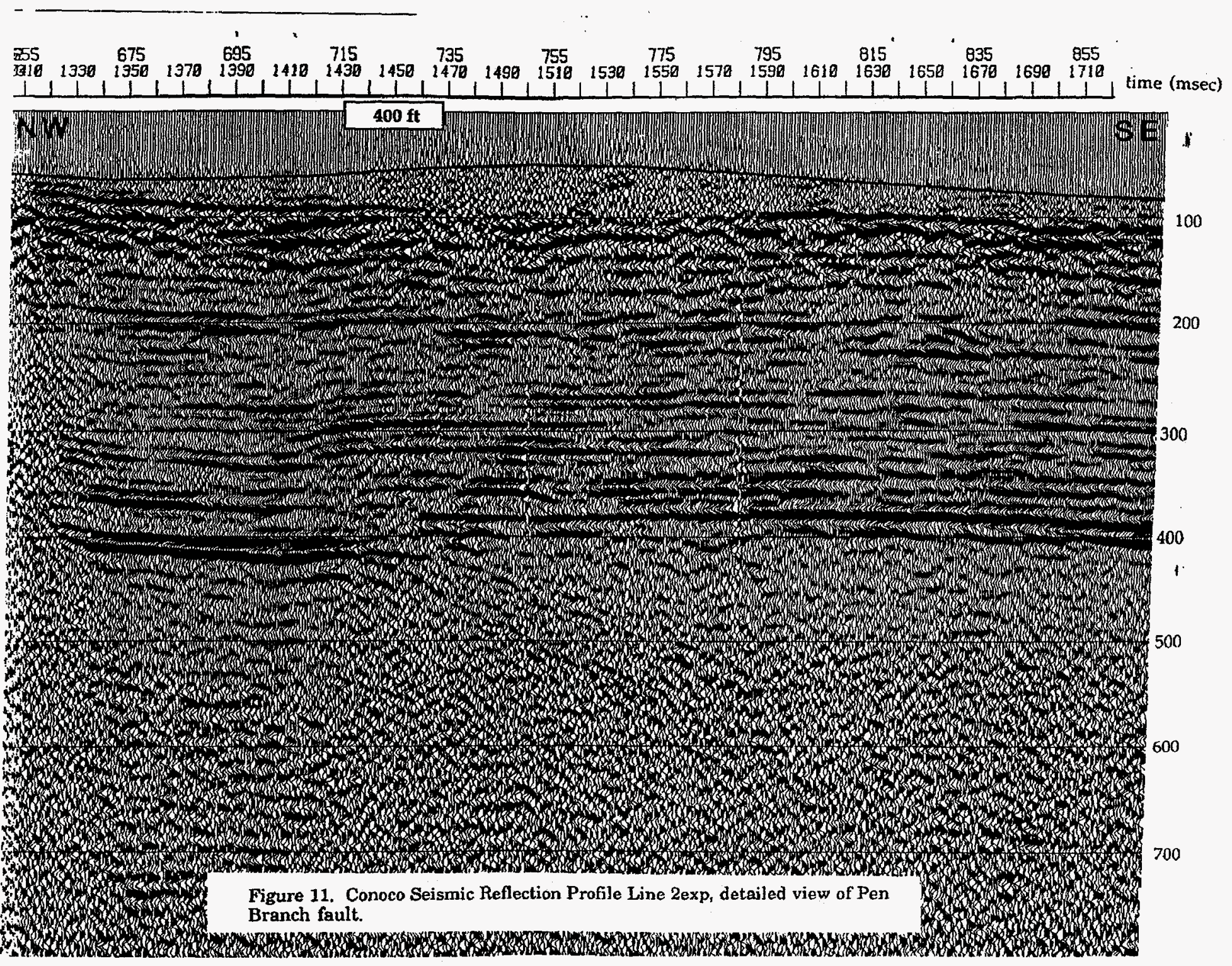




\section{NW

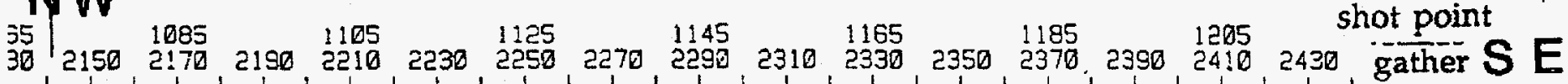

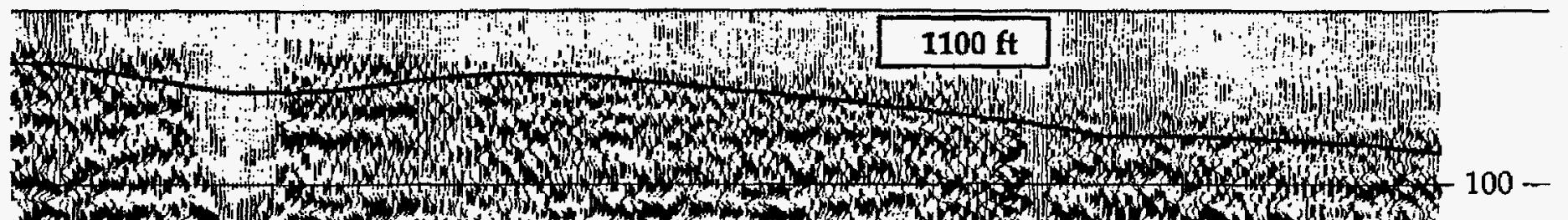

(4) ANow (y) S) 197.

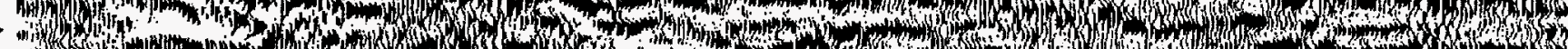

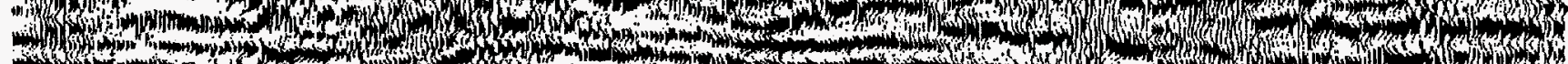
3.150

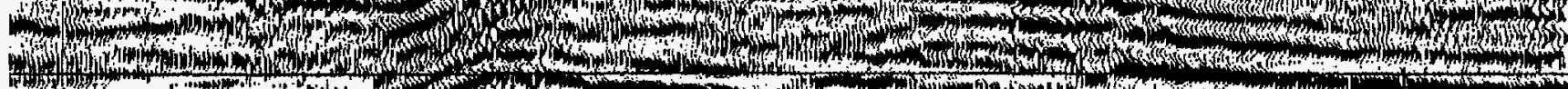
-

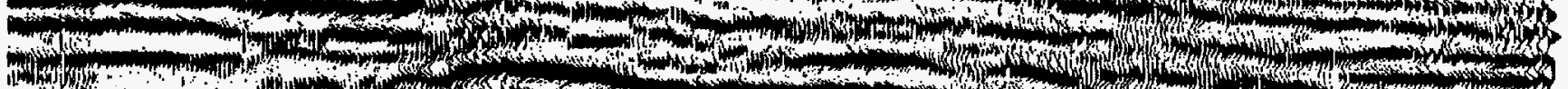
H.

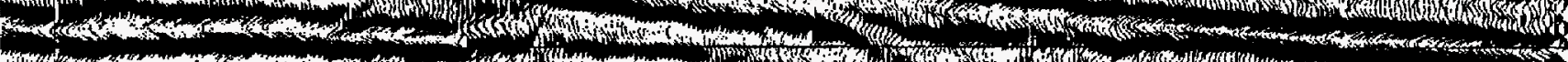

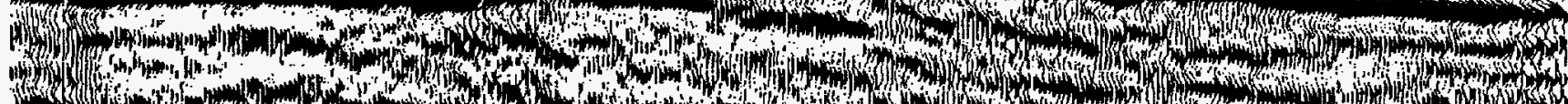
17 (1) 10 (3) i) D.

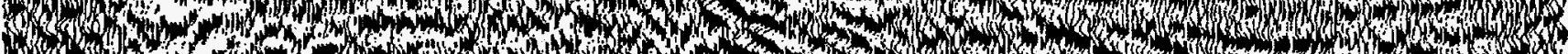

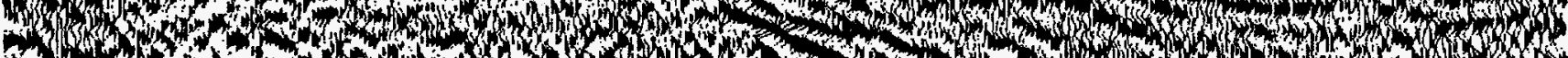
30 (6) 3.

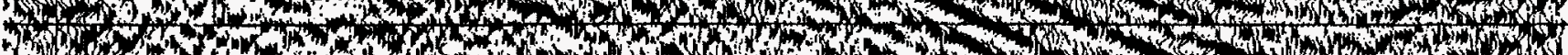

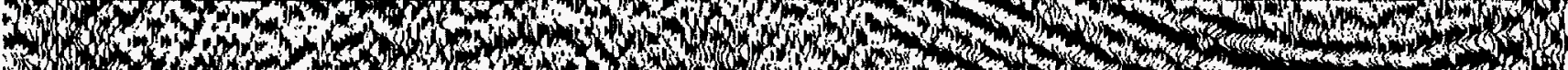

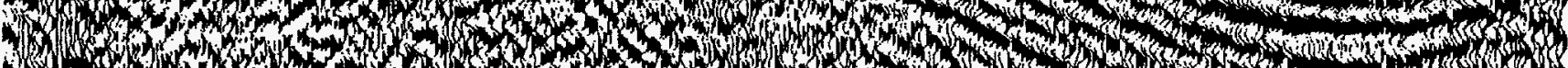
10. 1) 6)

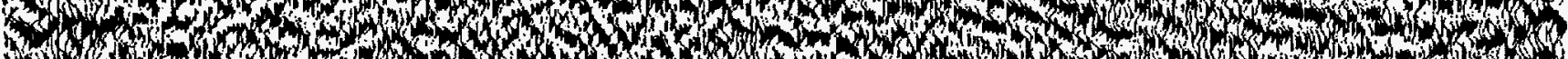

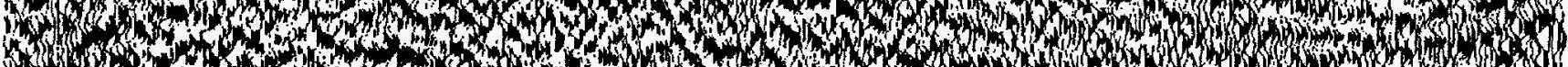

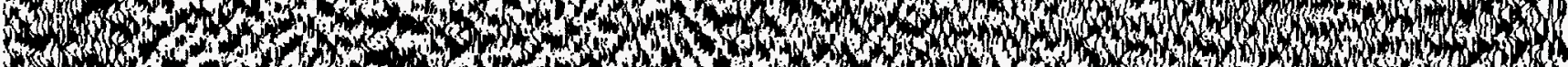

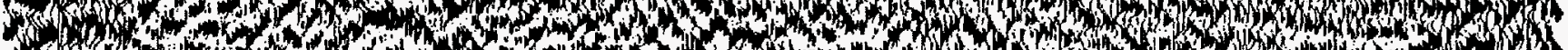

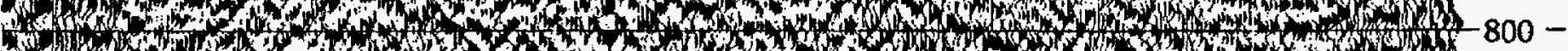
(3) (10)

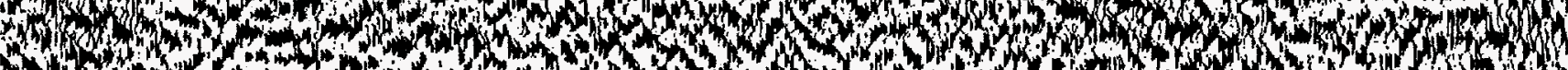
in

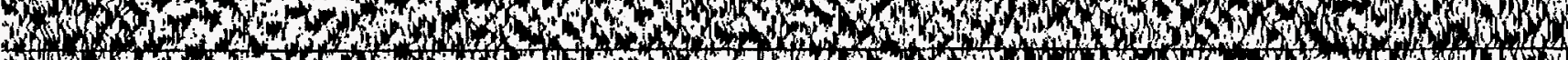

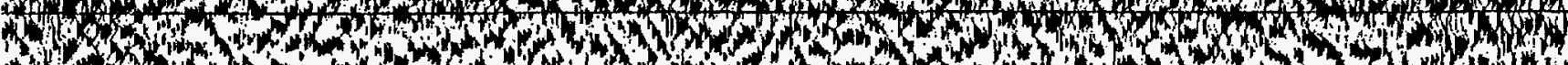

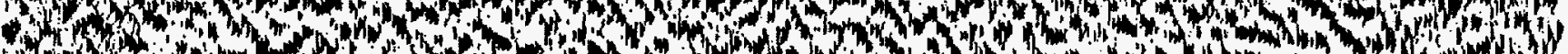

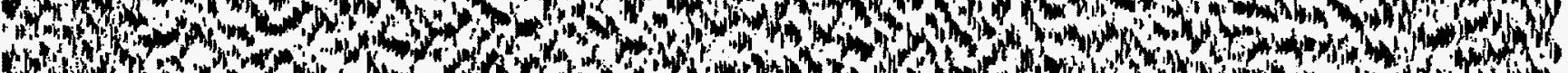

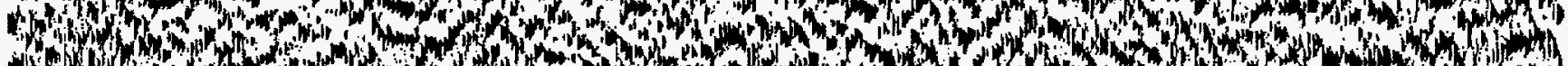

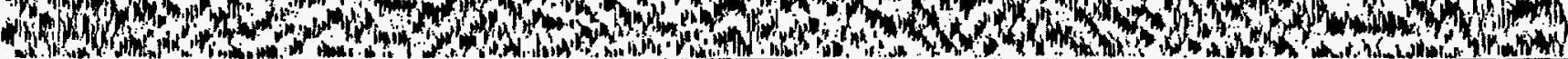

Figure 12. Conoco line 4 showing Pen Branch fault and inclined strata of the Dunbarton basin. 


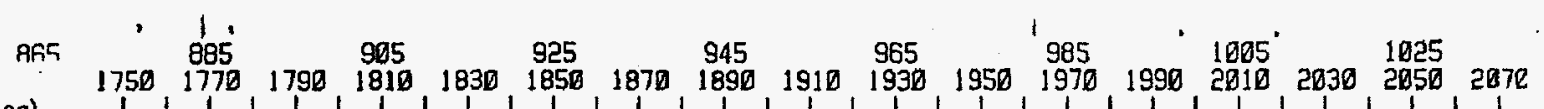

time (msec)

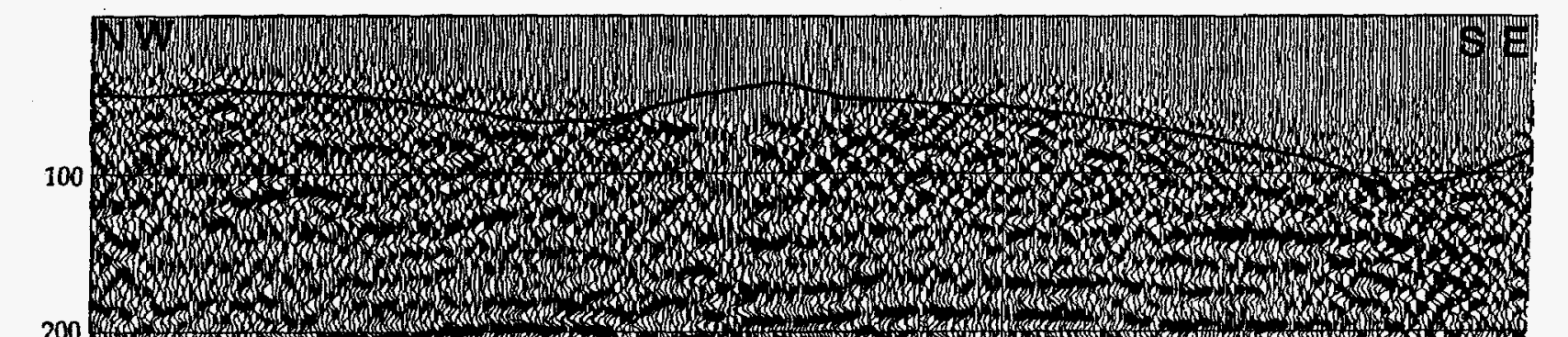

200

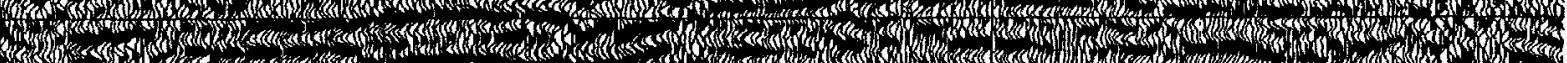

-

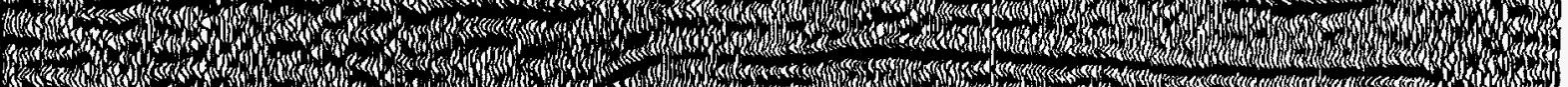

300

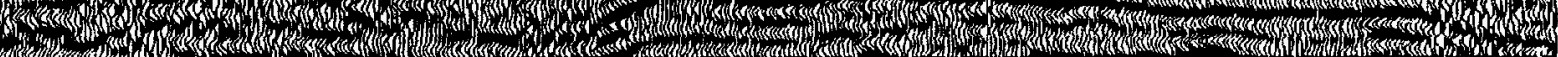

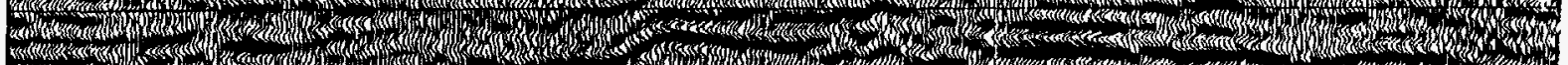

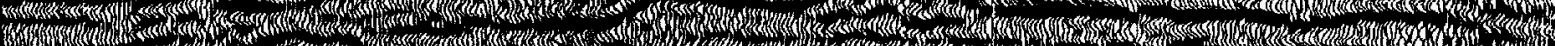

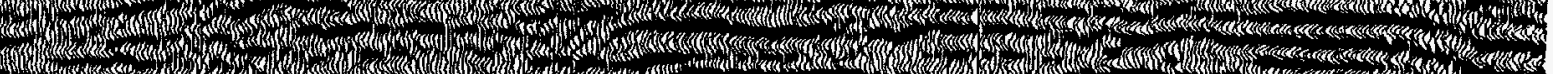

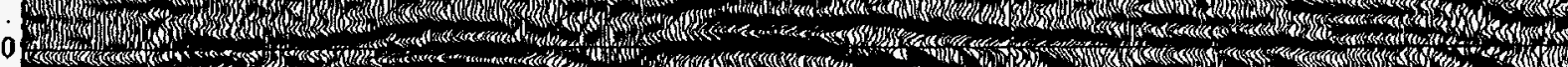

400 .

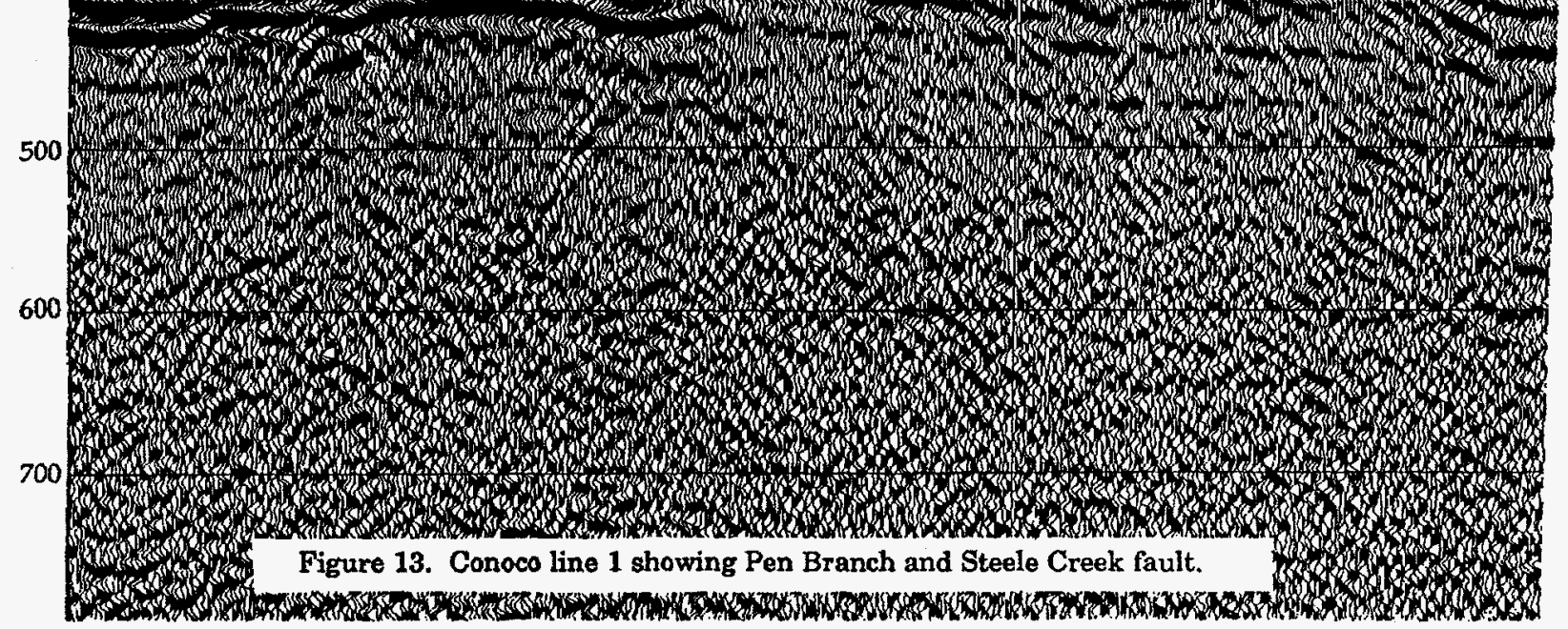

Figure 13. Conoco line 1 showing Pen Branch and Steele Creek fault.

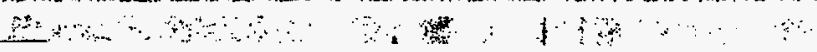


Anderson's (1990) detailed gravity survey shows a second order structure within the Dunbarton basin. This feature appears as a shelf on the contour map to the northwest of the deeper portion of the basin (Figure 7) and is thought to be the Steele Creek fault.

The Atta fault (AF) is located in the northeast quadrant of the Savannah River Site and strikes north-south. The attitude of the fault appears to be near vertical with marker horizons up to the east relative to the west. The reprocessed Conoco line 27 (Figure 14) indicates offset reflectors at -250 msec and draping reflectors up to $-150 \mathrm{msec}$ (shot point 100). The offset at basement is $25 \mathrm{msec}$. This line is the northern most seismic reflection data obtained for this feature. It also contains the largest offset expression of the Atta Fault. In the reprocessed Conoco line 9, offset reflectors of the AF are certain only below 350 msec (Figure 15, shot point 805 ) and not as distinct as in line 27. Offset amounts to $15-20 \mathrm{msec}$ at the basement level. Draping reflectors are observed, possibly, up to $150 \mathrm{msec}$.

The upward penetration of the Atta fault is uncertain in both of these lines because there are no good reflectors over the fault in the shallow section. The characteristic $200 \mathrm{msec}$. reflector from other lines in this survey would be expected at about $150 \mathrm{msec}$ in this area of the site. However, it does not appear to be well developed or even present. This may be due to thinning of the interval or a facies change in the interval that effectively erases the reflector.

Because other seismic lines south of line 9 (Conoco line 4, 10, 25) do not show any faulting, it is thought that line 9 may the the southern terminus of the Atta fault. These data suggest that the Atta fault neither intersects nor soles into the PBF. However, the Atta fault may extend further to the north beyond Conoco line 27.

Bouguer gravity (Anderson, 1990) may suggest the presence of the Atta fault by a disruption of a northeast trending gradient. At the interrupted southern extent of the fault is a closed contour gravity high of $-12 \mathrm{mgal}$. To the north and northeast are two otber small gravity highs that taken together disrupt the general northeast trend in the contour fabric. The Blackhawk TDEM survey exhibits a similar disruption in a northeast trending trough-like feature (Figure 10). There is a closed contour structure surface low in the same location as the Bouguer gravity high. The Atta fault may be expressed as the shallowing gradient due west of this feature.

The Crackerneck fault is located in the northwestern part of the Savannah River Site. The fault strikes north-northeast and is down to the northwest. The fault was recognized on Conoco line 1 and 4, but the lateral extent was not determined from the seismic reflection data. The reprocessed Conoco indicate the Crackerneck fault at shot point 140-145 on line 1 (Figure 16). The basement reflector at $-300-350 \mathrm{msec}$ is clearly offset about 20 msec. There may be some deformation in the shallow section up to $250 \mathrm{msec}$. However, there are essentially no marker horizons developed in this area of the profile to indicate the shallowest extent of the fault. The Crakerneck fault does not appear to penetrate through the Cretaceous section. A single seismic line from Seismograph Services Corporation ran to the northwest of the site and the structure contour map 


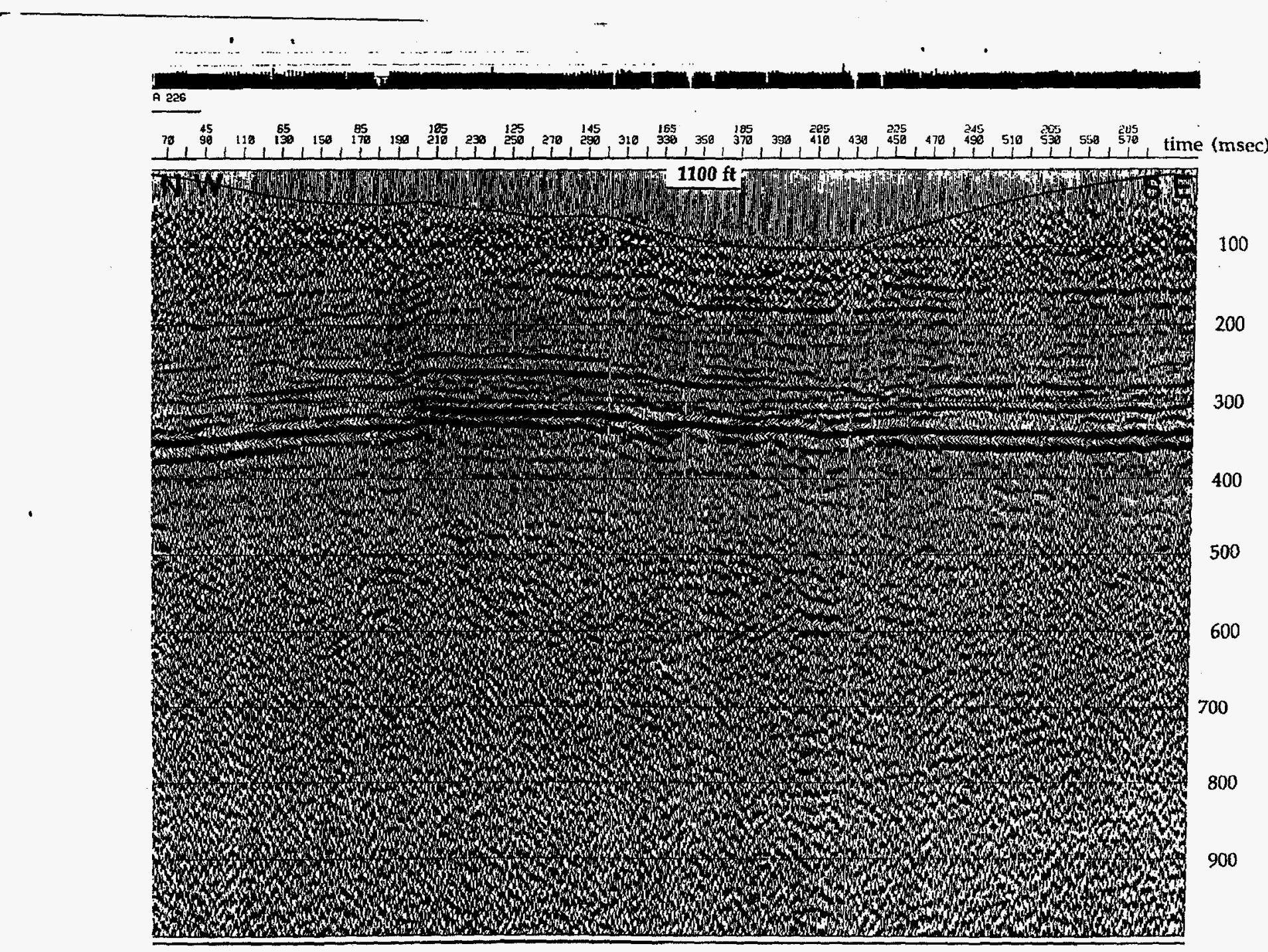

Figure 14. Conoco line 27 Atta fault, northern line.

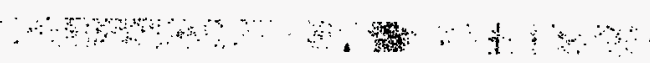




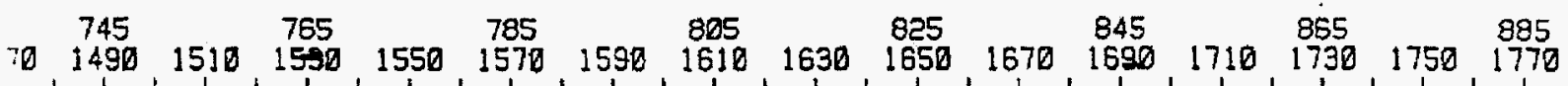

time (msec)



Figure 15. Conoco line 9 Atta fault, southern line. 


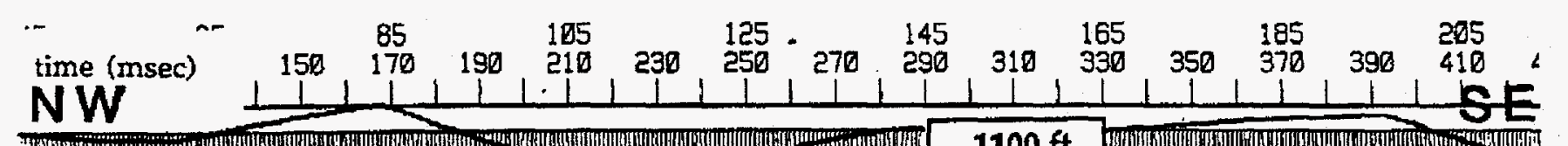

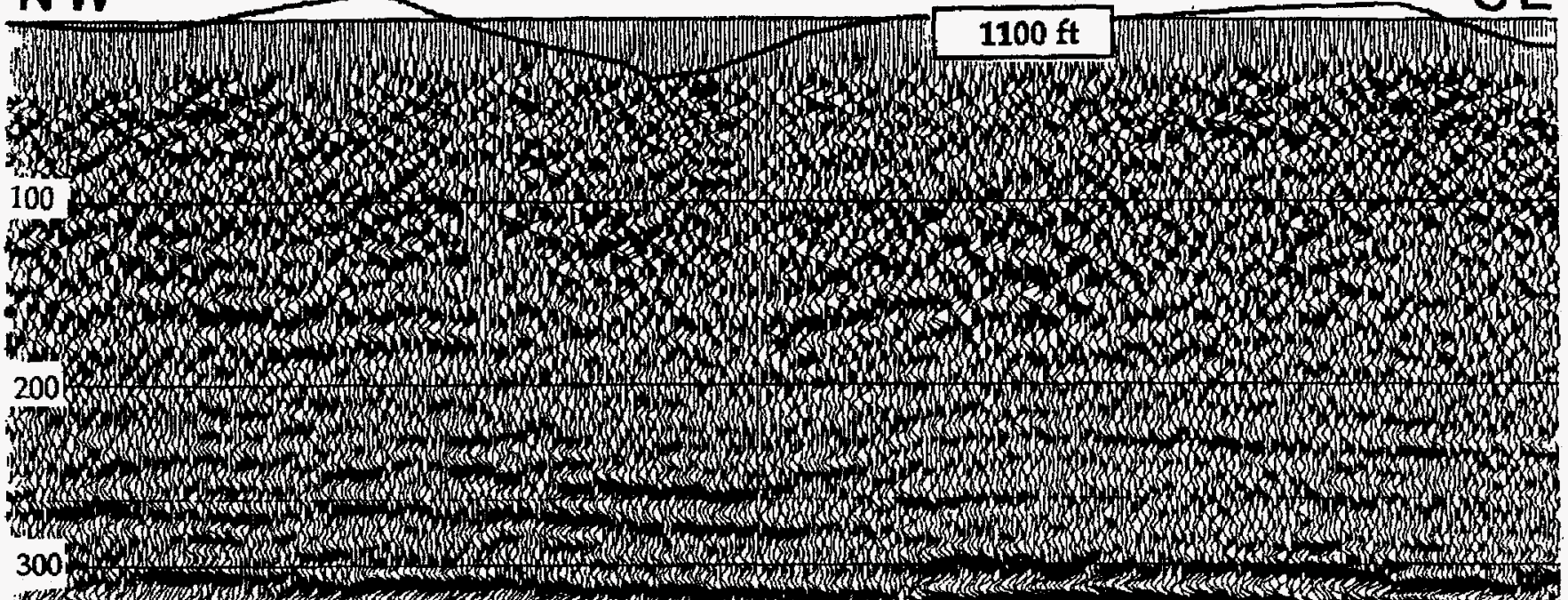

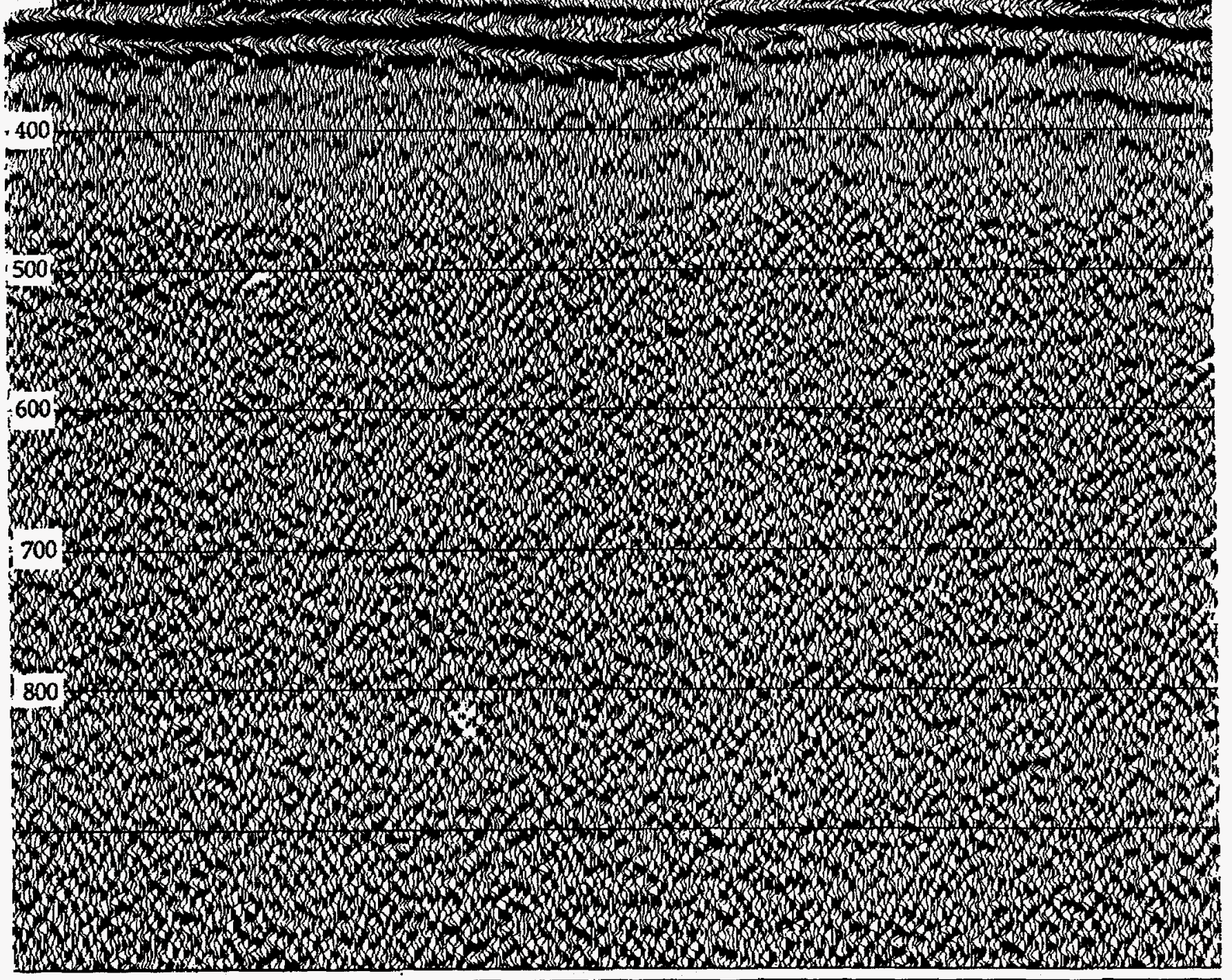

Figure 16. Conoco line 1; Crackerneck fault. 
prepared from that data indicate a fault approximately where Conoco later interpreted the Crackerneck fault.

The Crackerneck fault is located at the northwest edge of a descending Bouguer gravity gradient (Figure 7). Deflections in the trend of that gradient may be bends in the fault or a set of en echelon faults in that line. The Crackerneck fault may be interpreted in the aeromagnetic data as a northwest trending lineation feature in this corner of the site (Figure 8).

The Ellenton fault is located in the southeast quadrant of the Savannah River Site and can be observed in Conoco lines 6, 21, and 23. The fault strikes north, northwest, dip is thought to be near vertical and the block to the east is down thrown. The Ellenton fault is not known to intersect the PBF, but it is suspect. The fault is not recognized on line 7, which constrains the southwest extent of the fault. The reprocessed Conoco data does not clearly indicate the presence of this fault. Seismograph Services Corp seismic reflection data indicate a small fault at the location of the Ellenton fault.

Upper Three Runs fault (Cumbest and Price, 1989a) is located in the northwest quadrant of the study area and trends northeast. As observed in seismic reflection data the fault is restricted to crystalline basement (Figure 17). The fault dips shallowly to the southeast and may sole into the Augusta fault further to the southeast, beneath the Dunbarton basin. Because the basement/Coastal Plain reflector is never observed to be offset or deformed where the fault is projected to this surface it is thought that the fault is probably Paleozoic. The youngest possible age is constrained to at least Jurassic time. The 6 second seismic section from the reprocessed Conoco line 4 is a useful line to integrate the previously discussed faults with respect to relative age and tectonic setting.

Upper Three Runs fault can be traced to its shallowest extent just beyond Upper Three Runs Creek data gap at station 385. This fault is thought to be a collision related deformation and is expected to demonstrate thrust fault geometry. Immediately underlying this structure is another package of dipping reflectors that project to the basement/Coastal Plain contact north of the site. This structure is interpreted as the Augusta fault. The Augusta fault is imaged as a collection or package of strong reflectors and it is thought that this structure is represented by a thick zone of shearing and faulting, hence the multitude of reflectors. Upper Three Runs soles into the underlying Augusta fault beneath the Dunbarton basin and because of the geometric relationship an age relationship is implied. Reflectors from the Augusta-Upper Three Runs system is interrupted by vertically oriented bright zones beneath the Dunbarton basin and this is thought to be a series of basalt/diabase dikes and sills related to the extensional tectonic regime active during the initiation of the last cycle of rifting on the continental margin (Costain and others, $1992 \mathrm{a}$ andib; Domoracki and others, 1992; McBride and others, 1989).

The northern boundary of the Dunbarton basin is located at station 1100 and the Pen Branch fault can be observed disrupting Coastal Plain strata at this point. The rift related strata beneath the Coastal Plain, proximal to the Pen Branch fault are dipping southeast. Further the Pen Branch fault is not observed to sole into 


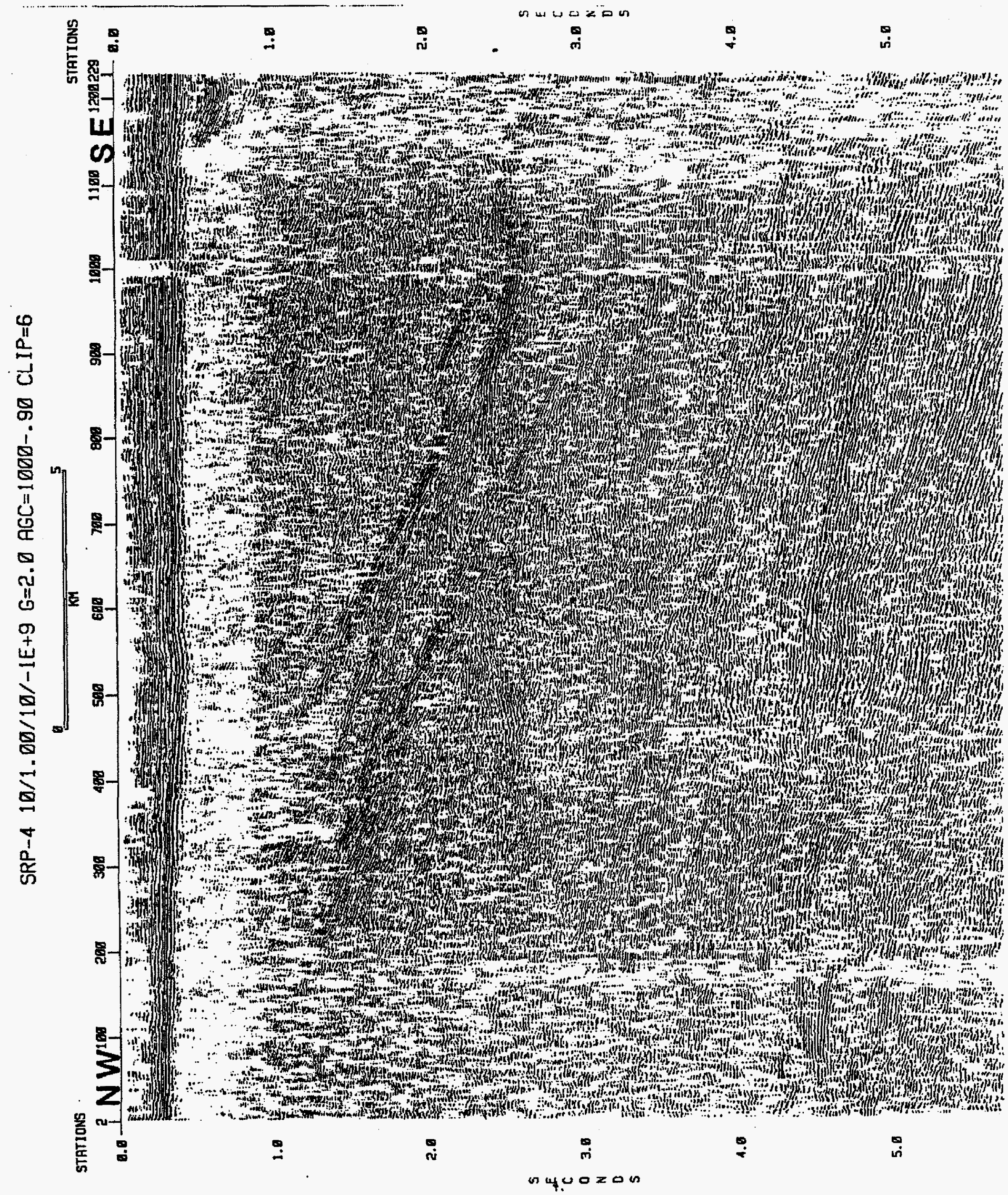

Figure 17. Conoco line 4; 6 second record showing Pen Branch fault, Dunbarton basin, and Upper Three Runs and Augusta faults. 
the Augusta-Upper Three Runs fault system. On the southeastern side of the basin, observed on Conoco line 13 (Figure 18) strata in the basin are dipping northwest. These layers are interpreted to be basalt sills that intruded along earlier formed strata in the rift basin (Domoracki and others, 1992). These bright reflectors may point to the border of the Dunbarton basin. The presence of basalt is corroborated by potential field data.

The southeastern boundary of the basin is not well understood. Faye and Prowell (1982) interpreted the presence of the Millett fault (Figure 2) based on two drill holes located just beyond the southern boundary of the Savannah River Site. Potential field data suggest a southeastern terminus to the basin in the approximate location where Faye and Prowell placed the Millett fault. However, the exact nature of this boundary is yet to be determined.

The thickness of the basin is not well constrained. DRB-9 core entered crystalline rock beneath Triassic sedimentary rock a $-711 \mathrm{~m} \mathrm{msl}$ (Figure 19). Lewis (1974) postulated $1.52 \mathrm{~km}$ of displacement on the northwest border fault (PBF). The recent seismic reflection data indicate the northwest side of the basin to be about 2 second two way travel or about $2.5 \mathrm{~km}$ deep.

Southeast of the Dunbarton basin aeromagnetic and gravity data indicate a terrane heavily influenced by basalt flows and sills. The magnetic data contain numerous high frequency closed contour features indicative of shallow structures and lower frequency features indicative of deeper seated features. The host rock is perhaps crystalline metamorphosed rock similar to what is found further to the northwest beneath the Savannah River Site. In addition, Madabhushi and others (1992) suggest this is a terrane separating the Piedmont orogeny from crust of different affinity further to the southeast. The mafic intrusions in effect define the southeastern boundary of the Dunbarton basin and the northern boundary of the South Georgia Rift basin.

Beneath the Augusta-Upper Three Runs faults there are other packages of reflectors being truncated by or splaying off of the Augusta fault (Figure 16). Some of these reflectors dip northwest. At 4.0 secs is a reflector package interpreted to be a decollemont surface for the Blue Ridge thrust or perhaps the master detachment from the Mesozoic separation of North America from Africa.

\section{Regional Context}

In a regional context, the upper crust beneath Savannah River Site shows similar structures and relationships seen in other crustal sections in the southeastern Atlantic margin. These are rift or collision-related structures with faulting of various ages associated with the plate movement.

To the north west of the site, the Augusta fault crops out in Georgia and South Carolina and is offset $23 \mathrm{~km}$ in left-lateral movement by the Cenozoic Belair fault (Figure 20) ( Prowell and O'Connor, 1978; Bramlett and others, 1982). Geologic mapping indicated the Augusta fault was a late Alleghanian, northeast striking thrust fault. The fault coincides with a string of magnetic anomalies (Hatcher and others, 1977) and there is an early ductile ghear fabric overprinted with brittle 


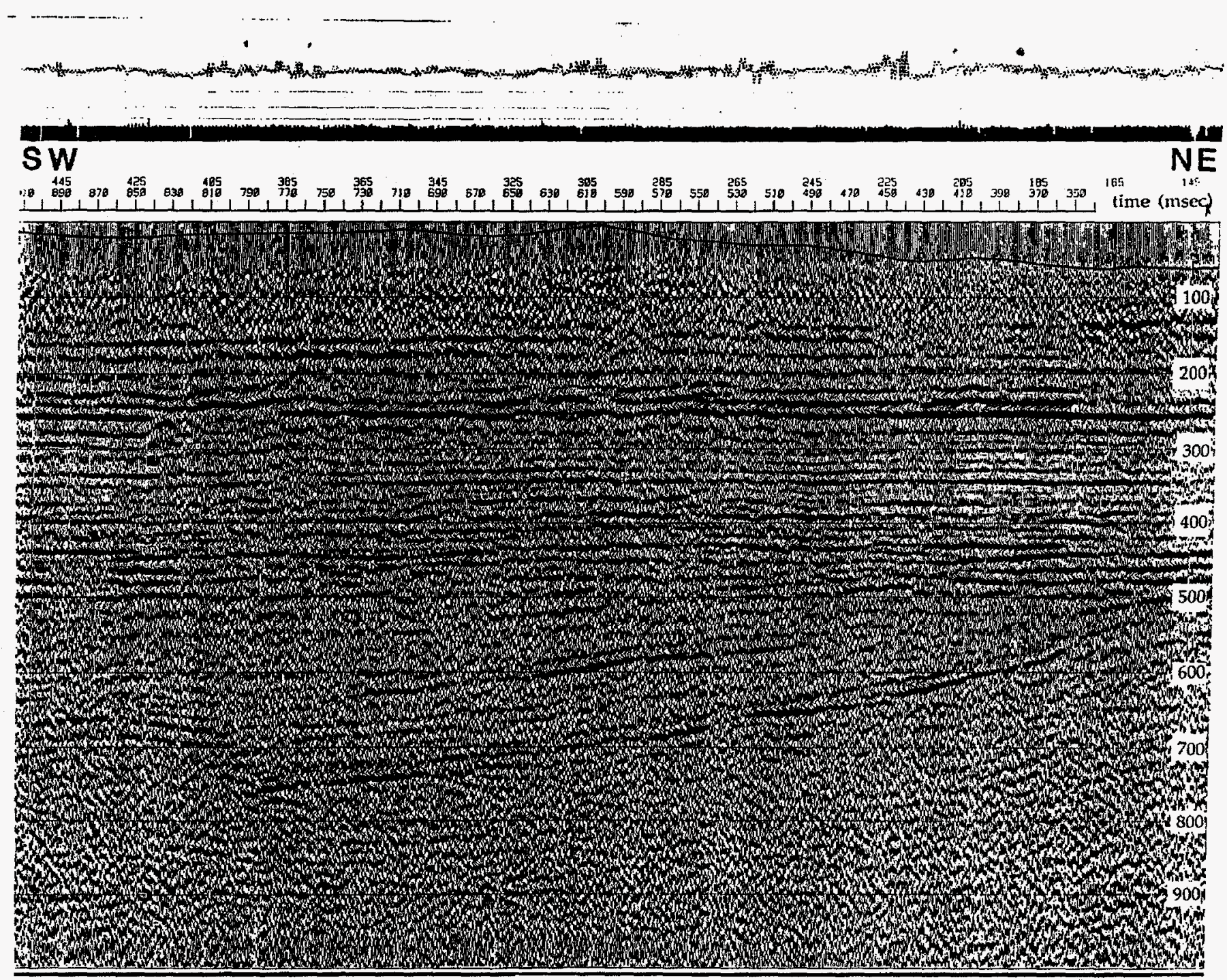

Figure 18. Conoco line 13, Southern boundary of the Triassic basin showing mafic sills.

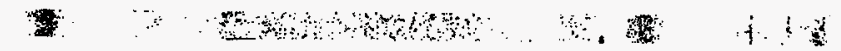




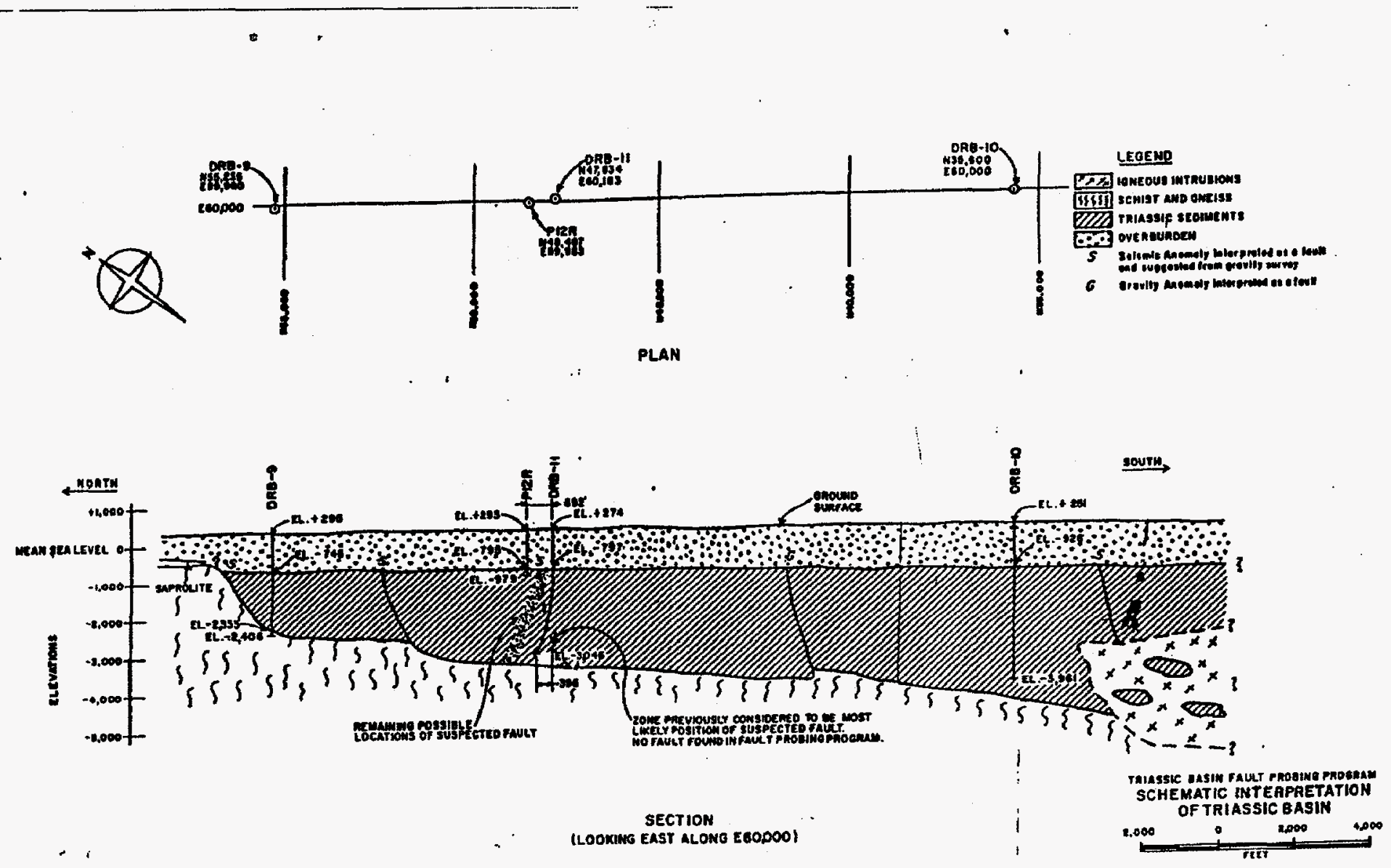

Figure 19. Cross-section of the Dunbarton basin from Triassic Basin Fault Probing Program Report, 1973, E. I. DuPont De Nemours and Co. 
-

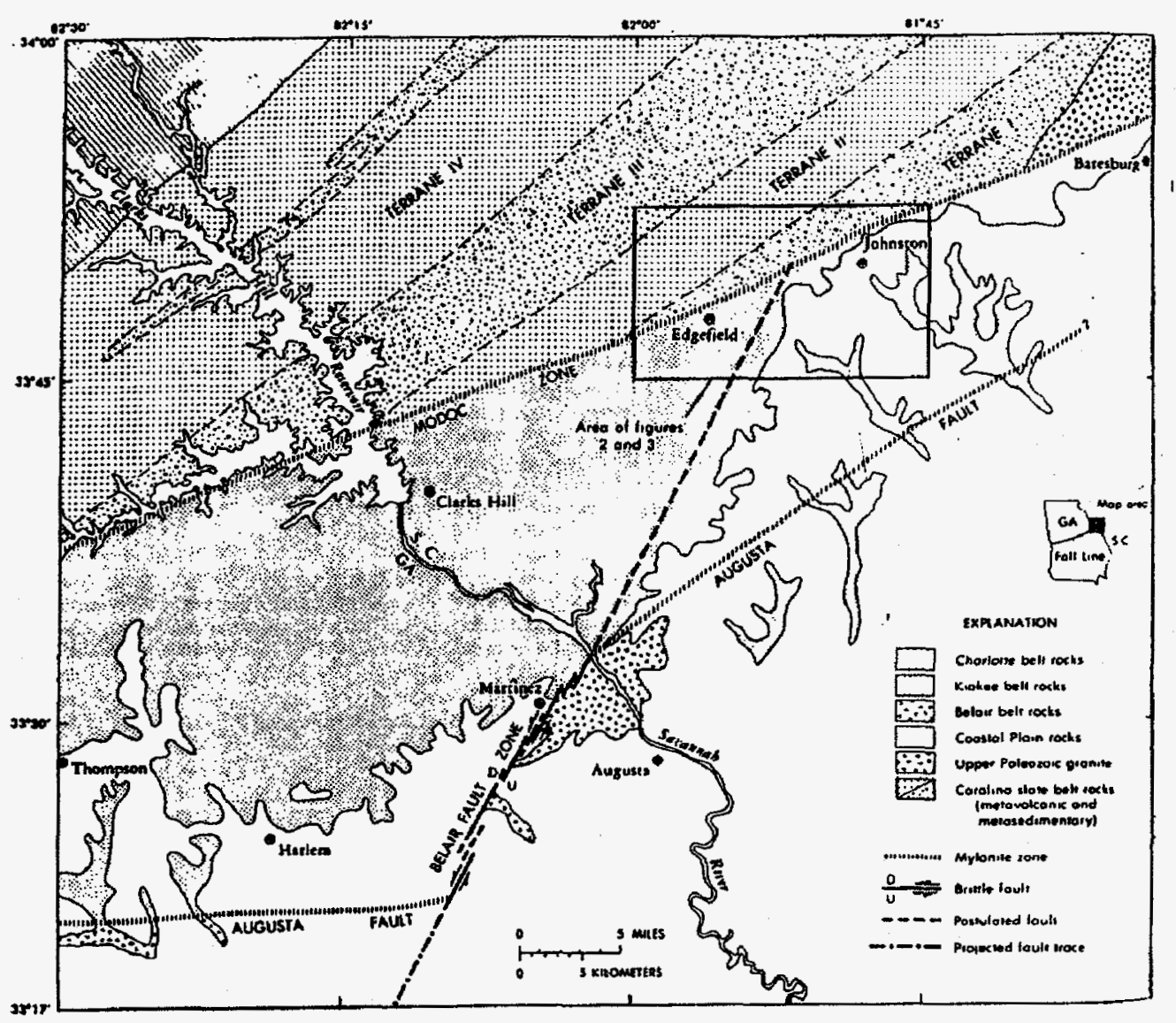

Figure 20. Geologic map showing the Augusta and Belair faults in Georgia and South Carolina (from figure 1 Bramlett and others, 1982). Savannah River Site is located just off the lower right hand corner of illustration. 
fabric (Bramlett and others, 1982). COCORP data (Cook and others, 1981) traced the shallow southeast dipping fault $60 \mathrm{~km}$ to the south. Bramlett and others concluded that the fault was a reverse or thrust type fault. More recent data (Maher, 1987) indicate that the ductile movement was normal sense displacement (down to the southeast) based on extensive shear sense indicators dated at $275 \mathrm{Ma}$ (latest Alleghanian orogeny). Normal fault movement is also supported by the position of greenschist facies Belair belt rocks in the hanging wall of the fault and amphibolite facies Kiokee Belt rocks in the foot wall (low grade rock over high grade rock indicates normal separation). Based on the image of the Augusta fault beneath the Savannah River Site, it is clearly connected with Upper Three Runs fault. This has implications for similar displacement on the Upper Three Runs fault. Based on the shallow dipping geometry both faults look like thrust faults. However, both faults may be originally thrust fault features with reactivation in the Permian as normal faults. It is suggested that these faults are not associated with Mesozoic normal faulting. Further, both faults present no evidence of reactivation after the pre-Cretaceous unconformity.

The Augusta-Upper Three Runs system does not apparently connect with the Pen Branch fault system within the constraints of our data. This is a significant observation because of the Cenozoic reactivation issue associated with the Pen Branch fauit. As indicated in Figure 21, it is thought that the Augusta-Upper Three runs fault connects with the master detachment of the South Georgia Rift basin further to the southeast or in fact be truncated by that fault system (Stephenson and Stieve, 1992).

Younger than the Augusta-Upper Three Runs faults are the Pen Branch fault and its associated Dunbarton Triassic rift basin. Fault-bounded basins of Triassic-Jurassic age occur throughout the eastern North American continental margin. Many of the basins underlie the Atlantic Coastal Plain and offshore regions (Figure 22). Structurally, the basins are grabens or half grabens, formed by crustal extension during Late Triassic-Early Jurassic rifting that preceded Middle Jurassic opening of the Atlantic Ocean (Manspeizer, 1978; Petterson and others, 1984; McBride and others, 1989; Mc Bride, 1991). Generally, the basins are elongated in a northeast-southwest direction and are bounded by normal faults on one or both sides. Strata within the basins consist mainly of non-marine sandstone, conglomerate, siltstone, and shale. Carbonate rocks and coal are found locally in several basins. Igneous rocks of basaltic composition occur as flows, sills, and stocks within the basins and as extensive dike swarms within and outside the basins (King, 1971).

Geophysical data, including regional COCORP seismic reflection data, and drill hole data show a large Mesozoic rift complex beneath Coastal Plain strata from southwestern Georgia to southeastern South Carolina to off-shore North Carolina(Figure 22) (McBride and others, 1989). The South Georgia Rift basin covers an expansive area beneath the southeastern Coastal Plain and comprises a complex system of interconnected basins containing variable thickness of Mesozoic strata (Chowns and Williams, 11983; McBride and others, 1989; Daniels and others, 1974; Nelson and others, 1985). Drill hole data in addition to seismic reflection data indicate the presence of extensive basalt flows and diabase sills (McBride and others, 1989). McBride (1991) presented evidence from COCORP 


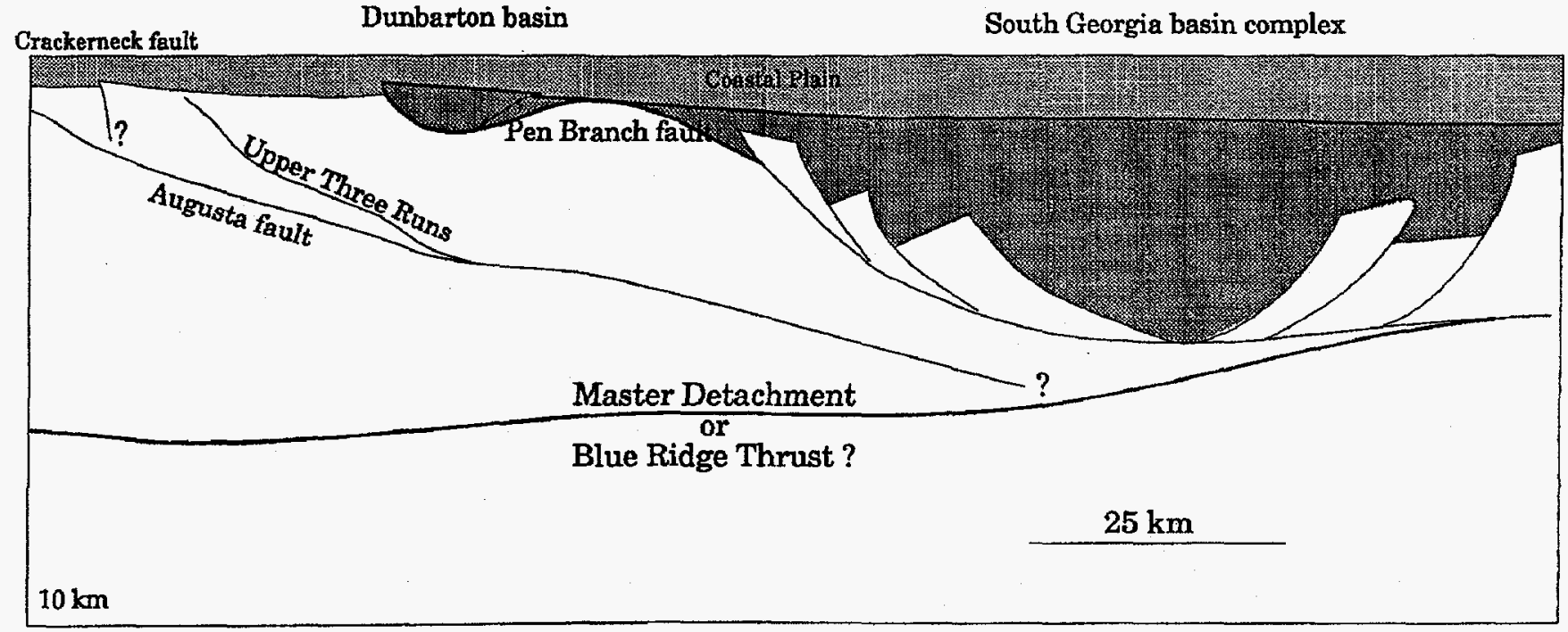

Figure 21. Geologic cross-section of nor thwest to southeast transect through SRS to the coast. 


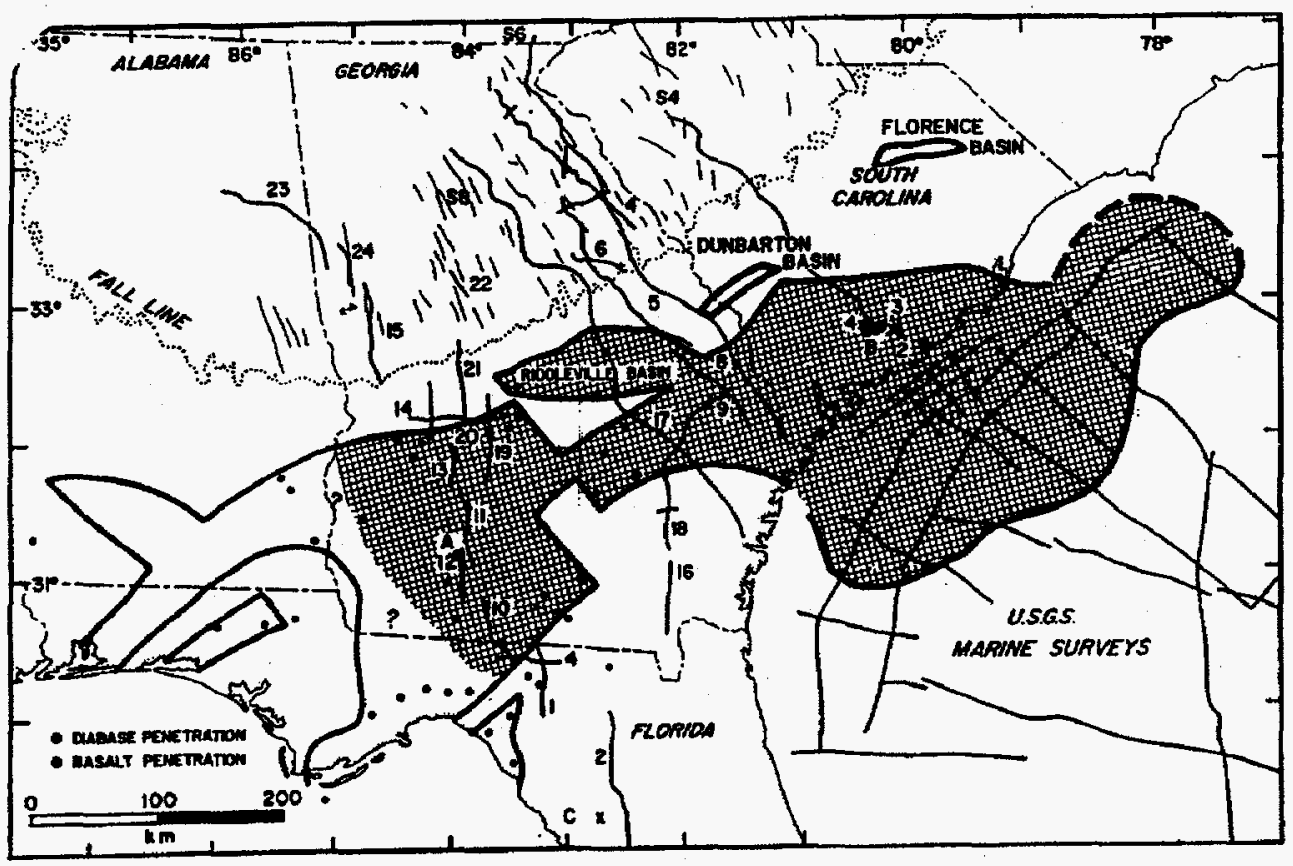

Figure 22. Southeastern regional map of subsurface Triassic basins (from Figure 1 of McBride and others, 1989). Heavy lines outline the Triassic-Jurasic subcrop, intermediate lines indicate seismic reflection data, and thin lines represent exposed diabase dike outcrops in the Piedmont. Dots indicate drill hole data. 
seismic reflection data that major sub-basin border faults within the South Georgia basin dip northward in antithetic relation to the predominantly northward vergence of the Alleghanian suture zone. The sub-basins developed mostly over the upper plate of the Alleghanian suture of North America and Africa. Most basins formed far south of the suture but some of the basins formed north of the suture in eastern Georgia. From these observations, McBride concluded that the border faults do not necessarily activate antecedent structure.

The smaller basins forming to the north of the South Georgia basin such as the Dunbarton and the Riddleville basins show a slightly different picture. The Riddleville basin is a small half graben to the southwest of the Dunbarton (Figure 20) with a major south-dipping master normal fault at its northern boundary that soles into the Augusta fault to the south(Petersen and others, 1984). This is similar to observations for the Dunbarton basin. The Pen Branch fault is the southeast dipping master fault to the Dunbarton basin. However, the current data suggests that the Pen Branch fault does not sole into the Augusta fault as the Magruder fault of the Riddleville basin does. Rather, the fault shallows to the southeast on the far side of the basin and than perhaps soles directly into the South Georgia basin complex (Figure 21).

Geometric and kinematic arguments from other study areas along the eastern continental margin suggest that early Mesozoic normal faults may be reactivated Alleghanian thrust faults (Peterson and others, 1984; Hutchinson and Klitgord, 1986; Ratcliffe, 1971; Linholm, 1977 and 1978; Glover and others, 1980). Other investigators have demonstrated a lack of coincidence between location of Triassic basins and earlier formed Alleghanian faults (McBride, 1991). Studies of the exposed and buried rift basins show that the faults controlling basin formation are complex, with border faults of variable dip, antithetic faults of variable magnitude, and cross or transfer faults that fragment the basin into sub-basins (McBride and others, 1989). The same may be true for the Dunbarton basin.

Mesozoic normal faulting initiated the formation of the Pen Branch fault. There was more displacement on this fault after the rift-drift period during the opening of the Atlantic basin. After tectonic extension, with the formation of downdropped blocks over a thinned continental crust, there was a period of erosion during the late Jurrasic and early Cretaceous that planed off the continental margin surface and made the triassic sediments level with the crystalline basement surface. The Atlantic ocean advanced onto the continental margin and began the deposition of Coastal Plain sediments during the middle to late Cretaceous. The Pen Branch fault began moving again with very low rates of displacement in a reverse sense movement. This slow intermittent movement continued through the Tertiary. Other nearby faults, such as the Belair fault also show reverse sense displacement off-setting Coastal Plain sediments from Cretaceous through Tertiary time (Bramlett and others, 1982). However, the Belair fault does not capture any Triassic sediments so it may not be a reactivated normal fault. Bramlett and others (1982) suggest that the Belair fault may originally be a tear fault of the Augusta sheet. Likewise, the Crackerneck and Atta faults that were discussed in this report offset young Coastal Plain sediments. The sense of displacement is interpreted to be reverse separation, although it can not be demonstrated with stratigraphic age constraints at this 
page 12

WSRC-TR-92-120

time. The period following extension was perhaps followed by an episode of crustal relaxation whereby the shallow crust flexed or moved upward and created local zones of compression resulting in the formation of these reverse faults. The Pen Branch and Belair faults contain evidence for reactivation. The Atta and Crackerneck faults may be new structures for this time period. There is no evidence that would suggest they are reactivated antecedent structures.

\section{CONCLUSIONS}

1. Basement/Coastal Plain surface dips southeast with minor highs and lows. There is a local dip to the west, southwest, toward the Savannah River channel. This surface is broken by several faults that penetrate Cretaceous through Tertiary horizons. The faults break the basement into discreet blocks with unique geophysical characteristics. They include but are not limited to: Pen Branch, Steele Creek, Crackerneck, Atta, and Ellenton faults. The blocks can also be separated based on seismic signature and potential field characteristics. To the south of the Savannah River Site is a block or terrane that separates Dunbarton basin from the South Georgia rift complex. It is predominantly a zone of mafic extrusion and intrusion. North of the Dunbarton basin, another block is characterized by several fault/reflector packages that are broken up underneath the basin by the mafic intrusions associated with the Triassic basin. These faults can be related to Alleghanian orogeny. Even further to the northwest the metamorphosed crystalline rock is influenced by granitic intrusions.

2. Upper Three Runs fault is an Alleghanian fault peneplained at the preCretaceous unconformity. There is no evidence to suggest reactivation in Cretaceous through Tertiary time. The fault soles into the Augusta fault beneath the Dunbarton basin and is related in age and mechanism to the Augusta fault.

3. The Pen Branch fault is a reactivated normal fault now showing reverse separation between crystalline basement and Triassic sedimentary rock. The Pen Branch fault, as the northwest boundary of the Dunbarton basin, dips southeast and apparently does not sole into the Augusta-Upper Three Runs fault system. This is in contrast to the Magruder fault of the Riddleville basin. The PBF may be the master fault for the Dunbarton basin and soles into one of the antithetic faults of the South Georgia rift complex further southeast.

4. The Pen Branch fault formed under extensional stress during Triassic time and reactivated during Cretaceous through Tertiary time under a compressive stress resulting in a reverse fault geometry. Fault geometry in the Coastal Plain section is observed be a complex of fault splays to the north and south of the master fault (eg. PBF forming horst with SCF). The Coastal Plain material may have behaved in a passive manner during displacement on the basement fault. The up-section limit of PBF as seen in seismic data is clearly offset up to $250 \mathrm{msec}$ and deformed up to $200 \mathrm{msec}$. 
5. The nearby Belair fault is described as a reactivated tear fault now showing reverse separation. It offsets young Coastal Plain sediments and suggests a corresponding age and mechanism for the Pen Branch fault. However, the Belair fault is not obviously connected to Triassic rifting as is the PBF. Other interpreted, young reverse faults in the area include Crackerneck, Atta, and Ellenton faults. Their relationship to the Cenozoic reverse fault system is unclear due to lack of data. However, similar mechanisms and timing may relate them all. 


\section{REFIRINCES}

Aadland, R. K. and H. W. Bledsoe, 1990, Classification of hydrostratigraphic units at Savannah River Site, South Carolina, USDOE Report WSRC-RP-90987, Savannah River Site, Aiken South Carolina.

Anderson, E. E., 1990, The seismotectonics of the Savannah River Site: The results of a detailed gravity survey, Master of Science Thesis, University of South Carolina, Columbia, South Carolina, 248 pp.

Berkman, E, 1991, Final Report high resolution seismic survey Pen Branch fault Savannah River Site, South Carolina: USDOE Report WSRC-TR-91-38, Savannah River Site, Aiken South Carolina.

Birdwell Division of Seismograph Services Corporation, 1972, Gravity and Magnetic Survey, Savannah River Plant, SC unpublished report prepared for E. I. DuPont de Nemours Co., Engineering Dept, Wilminton, DE.

Blackhawk Geosciences, 1989, Time Domain Electomagnetic Survey, Savannah River Plant, prepared for E. I. DuPont de Nemours and Co., Inc. Savannah River Laboratory, Aiken, Sc, 29802.

Bramlett, K. W., Secor, D. T., and Prowell, D. C., 1982, The Belair fault: a Cenozoic reactivation structure in the eastern Piedmont. Geological Society of America Bulletin, v.93, p.1109-1117.

Brown, L.D., Kaufman, S., 1985: New COCORP profiling in the southeastern United States. Part I: late Paleozoic suture and Mesozoic rift basin. Geology, v.13, p.714-718.

Chapman, W. L., and Di Stefano, M. P., 1989, Savannah River Plant Seismic Survey, 1987-88: Conoco Inc., Seismic Acquisition Section, Research Report 1809-005-006-1-89, $110 \mathrm{p}$.

Chowns, T.M., and Williams, C.T., 1983, Pre-Cretaceous rocks beneath the Georgia Coastal Plain regional implications, in Studies Related to the Charleston, South Carolina Earthquake of 1886- Tectonic and Seismicity, edited by G. S. Gohn, USGS Professional Paper1313, L1-L42.

Cook, F.A., Brown, L. D., Kaufman, S., Oliver, J. E, and Peterson T. A, 1981, COCORP seismic reflection prodiling of the Appalachian orogen beneath th Coastal Plain of Georgia: Geological Society of America Bulletin, Part I, v.92, p 378-748.

Coruh, C., Costain, J., Murathanoglu, M., 1992: Crustal estension, dikes and sills: Origin of crustal reflectivity: Geological Society of America, Southeastern Section Abstracts with Programs, v. 24, p . 
Costain, J., Coruh, C., Pappano, P., Domoracki, W., Sen, A., Stephenson, D. E., and Stieve, A., 1992a: Seismic expressions of structural styles of onshore Mesozoic basins concealed beneath the Atlantic Coastal Plain in eastern North America. Geological Society of America, Southeastern Section Abstracts with Programs, v. 24, p .

Costain, J., Coruh, C., Stephenson, D. E., and Stieve, A., Domoracki, W. J., Sen, A., Papano, P., 1992b, Seismic signature of Atlantic Coastal Plain sediments: Geological Society of America, Southeastern Section Abstracts with Programs, v. 24, p .

Cumbest, R. J., and Price, V., 1989b, Continued extension of the Dunbarton basin: An explantion for faulting in the Coastal Plain of South Carolina, USDOE Report WSRC-RP-89-1263, Savannah River Site, Aiken, SC.

Cumbest, R.J., and Price, V., 1989a, Extension of theeastern Piedmont tectonic system beneath Coastal Plain of South Carolina, USDOE Report WSRC-RP. 89-1299, Savannah River Site, Aiken, SC.

Daniels, D. L.,1974, "Geologic Interpretation of Geophysical Maps, Central Savannah River Area, South Carolina and Georgia." U.S. Geological Survey, Geophysical Investigation Map GP-893.

Domoracki, W. J., Sen, A. K., Coruh, C., Costain, J., Stephenson, D. E., and Stieve, A., 1992: Geometry of Dunbarton Triassic basin and related fault structures beneath the Savannah River Site, SC: Interpretations from seismic reflection data. Geological Society of America, Southeastern Section Abstracts with Programs, v. 24, p 12.

Faye, R. E. and Prowell, D. C., 1982, Effects of Late Cretaceous and Cenozoic faulting on the geology and hydrology of the Coastal Plain near the Savannah River, Georgia and South Carolina: U.S. Geological Survey Open-File Report 82-156, 85 p.

Glover, L.,III, Poland, F. B., Tucker, R.D., and Bourland, W. C., 1980, Diachronous Paleozoic mylonites and structural heredity of TriassicJurassic basins in Virginia: Geological Society of America, Abstracts with Programs, v. 12, p 178.

Hatcher, R. D.,Jr., Howell, D. E. and Talwani, P., 1977, Eastern Piedmont fault system-Specultions on its extent: Geology, v.5, no.10, p 636-640.

Hutchinson, D.R., and Klitgord, K. D., 1986, Evolution of rift basins on the continental margin off southern New England, in Manspeizer, Warren, ed., Triassic-Jurassic rifting: North America and Afric: American Association of Petroleum Geologists Memoir. 
King, P. B., 1971, Systematic pattern of Triassic dikes in the Appalachian regionSecond report: USGS Professional paper 750-D: Washington, USGS, D84D88.

Lewis, S., 1974, Significance of the vertical and lateral changes in the clay mineralogy of the Dunbarton Triassic basin South Carolina: unpublished M.S. thesis: Chapel Hill, University of North Carolina.

Lindholm, R.C., 1977, The Culpeper basin, Virginia: A case study in which Triassic tectonic patterns were inherited from preexisting structural fabrics: Geological Society of America, Abstracts with Programs, v. 9, p 1070.

Madabhushi, S., and Talwani, P., 1991: Shallow Crustal Structure Beneath the South Carolina Coastal Plain. EOS, Transactions, American Geophysical Union, p.428.

Madabhushi, S., and Talwani, P., Stephenson, D. E., 1992, Tectonics of South Carolina Coastal Plain region: A model based on potential field data: Geological Society of America, Southeastern Section Abstracts with Programs, v. 24, p 28.

Maher, H. D., 1987, Kinematic history of mylonitic rocks from the Auguata fault zone, South Carolina and Georgia: American Journal of Science, v. 287, p. 795-816.

Manspeizer, W., Puffer, J.H. and Cousiminer, H.L., 1978, Separation of Moroco and eastern North America: A Triassic-Liassic stratigraphic record: Geological Society of America, Bulletin, v. 89, p 901-920.

Marine, I. W., 1974a, Geohydrology of a buried Triassic basin at Savannah River Plant, South Carolina: American Association of Petroleum Geologists Bulletin, v. 58 p. $1825-1837$.

Marine, I. W., and Siple, G. E., 1974, Buried Triassic basin in the Central Savannah River Area, South Carolina and Georgia : GSA Bull. v. 85 p. 311 320.

Marine,I. W., 1974b, Geohydrology of the buried Triassic basin at the Savannah River Plant, Groundwater, vol 12, 96 pp.

Mc Bride, J. H., Nelson, K.D., Brown, L. D., 1989, Evidence and implication of an extensive early Mesozoic rift basin and basalt/diabase sequence beneath the southeast Coastal Plain; Geological Society of America Bulletin, vol 101, p. $512-560$.

McBride, 1991, Constraints on the structure and tectonic development of the early Mesozoic South Georgia Rift, southeastern United States; seismic reflection data processing and interpretation; Tectonics, v. 10, no. 5, p 1065-1083. 
page 17

WSRC-TR-92-120

Murdock, J. S., 1982, Preliminary Safety Analysis Defense Waste Processing Facility: E. I. du Ponte de Nemours and Co., Savannah River Laboratory, DPST-82-675, 4 volumes, prepared for the DOE under contract DE-AC0976 SR00001.

Nelson, K. D., Arnow, J.A., McBride, J.H., Willemin, J.H., Huang, J., Zheng, L., Oliver, J.E.,

Petersen, T. A., L. D. Brown, F. A. Cook, S. Kaufman, and J. E. Oliver, 1984, Structure of the Riddleville Basin from COCORP seismic data and implications for reactivation tectonics. Journal of Geology, v. 92, pp. 261271.

Petty, A.J. , Petrafesco, F. A., and Moore, F. C. Jr., 1965, Aeromagnetic map of the Savannah River Plant Area, South Carolina and Georgia, United States Geological Survey Geophysical Investigations Map GP 489.

Prowell, D. C. and O'Connor, B. J., 1978, Belair fault zone: Evidence of Tertiary fault displacement in eastern Georgia; Geology, v. 6, p.681-684.

Ratcliffe, N.M., 1974, The Ramapo fault system in New York and adjacent New Jersey: A case of tectonic heredity: Geologic Society of America, Bulletin, v. 82, p. 125-142.

Siple, G.E., 1967, Geology and ground water of the Savannah River Plant and vicinity, South Carolina: U.S. Geological Survey Water Supply Paper No. 1841, $113 \mathrm{p}$.

Snipes, D. S., Fallaw, W. C., Price, Jr., V., 1989, The Pen Branch Fault: Documentation of Late Cretaceous-Tertiary faulting in the Coastal Plain of South Carolina (U), Westinghouse-SRS, DP-MS-88-219.

Steele, K.B., and Colquhoun, D.J., 1985, Subsurface evidence of the Triassic Newark Supergroup in the South Carolina Coastal Plain: South Carolina Geology, v. 28, p. 11-22.

Stephenson, D. E., 1988, August 1988 Savannah River Plant Earthquake: E. I. du Pont de Nemours \& Co., Savannah River Laboratory, Aiken, South Carolina, DPST-88-841, p. 1-12, 6 figures.

Stephenson, D. E., and Stieve, A., 1992, Structural model of the basement based on geophysical data in the Central Savannah River Area, South Carolina and Georgia: Geological Society of America, Southeastern Section Abstracts with Programs, v. 24, p 68.

Stephenson, D. E., Talwani, P., and Rawlins, J., 1985, Savannah River Plant earthquake of June 1985: E. I. du Pont de Nemours \& Co., Savannah River Laboratory, Aiken, South Carolina, DPST-85-583, p. 1-31, 13 figures, 2 tables. 
Stephenson, D. S. and Chapman, W. L., 1988, Structure associated with the buried Dunbarton basin, South Carolina from recent seismic data. Geological Society of America, Southeastern Section Abstracts with Programs, v. 20, p 318.

Stieve, A. L., 1991, Pen Branch Fault Program: Interim report on the highresolution, shallow seismic reflection surveys (U):USDOE Report WSRCTR-91-30, Savannah River Site, Aiken South Carolina.

Stieve, A.L., Stephenson, D., Aadland, R., 1991, Pen Branch Fault Program: consolidated report on the seismic reflection surveys and the shallow drilling (U):USDOE Report WSRC-TR-91-87, Savannah River Site, Aiken South Carolina.

Talwani, P., Rawlins, J. and Stephenson, D. E., 1985, The Savannah River Plant, South Carolina, earthquake of June 9, 1985 and its tectonic setting, Earthquake Notes, v. 56 no. 4, p. 101-106. 